\title{
The Mental Representation of Semitic Words
}

\author{
Jean-François Prunet \\ Renée Béland \\ Ali Idrissi
}

\begin{abstract}
This article is concerned with external evidence bearing on the nature of the units stored in the mental lexicons of speakers of Semitic languages. On the basis of aphasic metathesis errors we collected in a single case study, we suggest that roots can be accessed as independent morphological units. We review documented language games and slips of the tongue that lead to the same conclusion. We also discuss evidence for the morphemic status of templates from aphasic errors, language games, and slips of the tongue. We conclude that the available external evidence is best accounted for within a morpheme-based theory of morphology that forms words by combining roots and templates.
\end{abstract}

Keywords: roots, templates, Semitic, metathesis, morphology, aphasia

Know that the biradical root may be permut[ed] in two ways, like qad - daq, šad - daš. The triradical root may be permut[ed] in six ways; this is called "six-way variation", like daraba - dabara - barada badara - radaba - rabada. The quadriradical root may be permut[ed] in twenty-four ways, because each of its four radicals may be combined with the six permutations of the triradical roots, making a total of twenty-four ways.

Al-Khaliil ibn ’Ạmad [born 718 cE, Oman, died 791, Persia], Kitaab al-'ayn

\section{The Nature of Semitic Lexical Units}

Does the mental lexicon contain fully formed words or morphemes that are concatenated by operations of affixation? In Semitic, the possibility of a morpheme-based lexicon has raised more concern than in other language families because it implies the existence of roots, that is, strings

The passage used as our epigraph was translated by Versteegh (1997:24) from al-Makhzuumii and as-Saamarraa'ii 1988:47-48.

We are grateful for comments and discussions to two anonymous reviewers, as well as to Hamza Al-Mozainy, Maya Arad, Degif Petros Banksira, Berhanu Chamora, François Dell, Anna-Maria Di Sciullo, Girma Halefom, Djaouida Hamdani-Kadri, Beth Hume, Marie Labelle, Wolf Leslau, David Levy, Irit Meir, Robert Ratcliffe, Keren Rice, Anne Rochette, Yvan Rose, Ur Shlonsky, Mohamed Soudany, Bezza Tesfaw, and Baye Yimam; audiences at the 1998 Current Trends in Phonology II conference (Abbaye de Royaumont, France), the 1999 Academy of Aphasia Meeting (Santa Fe, New Mexico, USA), the 1999 Conference on Phonological Encoding and Monitoring in Normal and Disturbed Language Production (Max Planck Institute for Psycholinguistics, Nijmegen, Holland), the 1999 Second Semitic Syntax Conference (University of Illinois at Urbana-Champaign, USA); and audiences at Addis Ababa University and Université du Québec à Montréal (UQAM). Special thanks are due to Mohamed Guerssel for comments made during a joint seminar on Semitic morphology at UQAM. Naturally, we are solely responsible for possible errors and omissions. This research benefited from SSHRCC grant 410-97-1335 and FCAR grant 98-ER-2305. 
of consonants (e.g., Arabic /ktb/, expressing the semantic field of writing). Semitic roots are abstract by virtue of the fact that they surface discontinuously, that is, separated by vowels adding morphological information (e.g., the perfective /a-a/ in katab 'wrote', or the passive /u-i/ in kutib 'was written'). Words are formed when roots are combined with a template and vocalic morphemes (e.g., katab 'wrote'). Some languages also have forms consisting solely of a root and a template, with epenthetic vowels, as in Moroccan Arabic ktib 'he wrote' and Inor Gurage dift' 'hit!'. On the other hand, in a word-based morphology the Semitic lexicon would not contain roots as independent morphemes. Instead, it would store vocalized words, such as /yaktub/ 'write(s)', and form related words through output-to-output mechanisms, that is, processes that take a fully formed word and turn it into another fully formed word (e.g., yaktub $\rightarrow$ katab 'wrote'). Let us note, however, that output-to-output rules can also be used by morpheme-based models, as long as the stored lexical units are morphemes, or at least words in which morphemic division is present underlyingly. As an alternative to both approaches, the lexicon could simply store all surface forms and express lexical relatedness through lexical correspondence rules.

Bohas and Guillaume's (1984) and Goldenberg's (1994) surveys of the notion of root in Semitic show that this debate has opposed linguistic schools of thought for centuries. Glossing over distinctions between verbal and nominal morphologies, we may distinguish two views. On the one hand, Arabic and Hebrew grammarians viewed Semitic roots as paradigmatic relations existing between fully formed words, rather than as autonomous morphemes. This view was later echoed in Saussure's (1978) associative series. Recent studies that likewise deny roots an autonomous lexical status include Mahadin 1982, Heath 1987, Bat-El 1994, Ratcliffe 1997, and Ussishkin 1999. This view implicitly or explicitly favors a word-based theory of morphology. On the other hand, structuralists such as Cantineau (1950) and Harris (1951) recognized roots as autonomous morphemes expressing the basic meaning of the word, additional morphological information being expressed by a distinct vocalized pattern. The latter view is echoed in autosegmental analyses such as those of McCarthy (1981) and Hoberman (1988), which typically further separate vocalized patterns into morphemes consisting of vowels only (such as /a-a/ and /u-i/) or templates only (to distinguish between kutib 'was written' and kuttib 'was caused to write'). Such analyses implicitly or explicitly adopt a morpheme-based theory of morphology since their lexicon includes roots such as $/ \mathrm{ktb} /$.

In this article, we will use evidence from aphasic metathesis errors we collected in a single case study to suggest that Arabic roots can be accessed as independent morphological units. The most likely formal interpretation of this access is that the Arabic lexicon contains roots. To show that these errors are not specific to aphasic speech, we will also review external evidence based on ludlings (i.e., language games) and slips of the tongue. We will also discuss external evidence for templates since Semitic word formation involves templates in all root-based and most wordbased theories. Finally, we will show that metatheses are pervasive in several areas of Semitic, and we will propose a formal explanation of the ease with which root consonants can be reordered.

\section{External Evidence for Roots}

The crux of our evidence comes from a case study of a bilingual Arabic-French aphasic patient. We will also discuss evidence from language games and slips of the tongue. In all three instances, 
we will show that Arabic stem consonants are prone to undergo metathesis. This specificity, we will argue, is better captured in models that hold that Arabic (and Semitic) underlying representations (URs) are different from those of other languages.

\subsection{Metatheses in Aphasic Speech}

2.1.1 Language Assessment ZT is an early Arabic-French bilingual. A native speaker of Lebanese Arabic, he started studying Standard Arabic and French at school in Lebanon at the age of 4 . He attended a bilingual school where sciences were taught in French and other subjects in Arabic. At the age of 22, he moved to Montreal, Canada, and attended a French-speaking university. He graduated as an engineer, then worked for eight years in companies where French was the main language used. ZT still spoke Arabic at home and with friends. At the age of 32, he suffered a stroke that resulted in a severe mixed aphasia, that is, a language deficit in which oral production and comprehension were impaired in both Arabic and French.

ZT was tested in Arabic and French by native speakers of the two languages at the same time post-onset. ${ }^{1}$ Testing was conducted one language at a time. ZT's output was immediately recorded and transcribed. Among the tasks that ZT was required to perform were reading aloud, repetition, oral and written picture naming, and writing to dictation. ${ }^{2}$

One year after the stroke, language assessments of ZT's Arabic and French showed mildly impaired oral comprehension of long and complex sentences. He did not, however, have difficulties understanding isolated words, which was the object of our testing. Oral production was found to be severely impaired, with the exception of word repetition. Writing and reading were severely impaired in both languages.

ZT's language impairment in both Arabic and French showed the characteristics of deep dyslexia. ${ }^{3} \mathrm{ZT}$ produces reading errors that are typically found in deep dyslexic patients: semantic errors (e.g., Arabic Pafyuun 'opium' $\rightarrow$ siigaara 'cigarette', French royal 'royal' [rwayal] $\rightarrow$ prince [prẽs] 'prince'), visual and/or semantic errors (e.g., Arabic نضال 'nidaal 'struggle, battle' $\rightarrow$ بط batal 'hero', French numéro [numero] 'number' $\rightarrow$ zéro [zero] 'zero'), morphological errors (e.g., Arabic Pa-zhaar. 'flowers' $\rightarrow$ zahr-a, 'flower', French goûter [gute] 'to taste' $\rightarrow$ goût

\footnotetext{
${ }^{1}$ We tried to control for dialectal variation in Arabic. Hence, ZT's deviations from Standard Arabic (SA) caused by interference from his Lebanese Arabic (LA) dialect were not regarded as errors (e.g., SA rižl 'leg, foot' $\rightarrow$ LA ?ižzir).

${ }^{2}$ In the reading aloud task, ZT was asked to read aloud fairly frequent isolated word stimuli. The error pattern in reading is similar in both the shallow (with diacritics) and the deep (without diacritics) Arabic writing system. This confirms that his reading impairment results from an output rather than an input deficit. The repetition task involved repeating a set of words after hearing them pronounced. In the picture-naming task, ZT was shown a picture and was asked to name its content either orally or in writing. In the writing-to-dictation task, words were read aloud and ZT was asked to write them down.

"Dyslexia is called "deep" when the acquired reading disorder is characterized by the production of semantic errors (e.g., tobacco read as cigarette). Deep dyslexia contrasts with surface dyslexia, a syndrome that involves the inability to read irregular words such as yacht. In the deep form of dyslexia, reading errors occur at a "deeper" semantic level, whereas in surface dyslexia, they arise from a surface-level impairment in decoding the written input. Thus, the word knife may be read as fork by a deep dyslexic but as [knarf] by a surface dyslexic.

${ }^{4}$ These errors are defined as visual and/or semantic because there is both a visual and a semantic resemblance between the target and the error.
} 
[gu] 'taste'), and phonemic errors (e.g., Arabic ?a-žfaan 'eyelids' $\rightarrow$ ?a-šbaan, French tâcher [taše] 'to endeavor' $\rightarrow$ [tašo]).

Because ZT produces semantic errors not only in reading aloud but also in picture naming, his language impairment corresponds to the "output form" of deep dyslexia. ZT produces semantic errors in Arabic and French in both oral reading and oral picture naming, not because of a disorder in accessing the semantic system (input form of deep dyslexia) or one affecting the semantic system itself (central form of deep dyslexia) but because he has difficulties accessing the phonological form of the word from an unimpaired semantic system (output form of deep dyslexia). ZT makes exactly the same types of errors in both languages but, we will show, he also makes metathesis errors much more frequently in Arabic than in French.

Full assessments of ZT's language performance by Mimouni et al. (1995) and Béland et al. (2000) revealed that he displays 9 of the 12 features of the deep dyslexia syndrome in both languages (see Plaut and Shallice 1993). These features refer to the error pattern (semantic, visual, morphological errors) and to the type of stimuli that are more sensitive to reading errors (function words, verbs, abstract words, nonwords). ${ }^{5}$ His pathology is absolutely parallel for all criteria in both languages.

2.1.2 Arabic and French Metatheses Among the errors that characterize ZT's performance in Arabic are frequent metathesis errors, which consist of modifying the linear order of root consonants. ZT produced these errors in all four tasks (reading aloud: 39/119 $=32.8 \%$; repetition: 38 / $119=31.9 \%$; writing to dictation: $17 / 119=14.3 \%$; picture naming: $25 / 119=21 \%$, for a total of 119 errors). In the course of this article, we will provide the whole corpus of metathesis errors in Arabic (and French) in the body of the text and tables. For convenience, the 119 Arabic metathesis errors are also listed in the appendix, sorted by roots in alphabetical order.

The examples in (1) illustrate two instances of consonant metathesis in each task. We will not indicate in the rest of the article the task from which the error was drawn. However, when produced in the writing-to-dictation task, the error will be quoted phonetically without short vowels to reflect ZT's Arabic transcription. The suffix $-t$ is the orthographic representation of the feminine phonetic suffix $-a$. Our interpretation of the word and gloss intended by ZT will be indicated as 'possibly $\mathrm{X}$ '.

\footnotetext{
${ }^{5} \mathrm{ZT}$ also displays four additional features specific to the output form of deep dyslexia. In both languages, (a) word repetition is almost unimpaired but nonword repetition is severely impaired, (b) oral picture naming is impaired, (c) lexical decision in visual and auditory input modalities is unimpaired (the lexical decision task requires the patient to answer YES or NO when asked if a stimulus presented auditorily or visually is a word; usually, half of the stimuli, presented randomly, are words and half are nonwords), and (d) implicit (i.e., "unconscious") access to the phonology of nonwords from visual print is preserved. In ZT's case, a significant cross-script homophone priming effect was obtained in a lexical decision task; that is, his reaction times are shorter in trials in which Arabic word stimuli are preceded by a homophonous French nonword prime than by a nonhomophonous prime. Note that the term output is used in psycholinguistics as synonymous with production. It means that the patient has problems producing but not understanding. It does not refer to the output of a derivation in formal linguistics.
} 
(1) Examples of consonant metathesis in Arabic

\begin{tabular}{|c|c|c|c|}
\hline Target & Output & Target gloss & Task \\
\hline Sušb & šuৎb & 'grass' & reading aloud \\
\hline fašil & šafil & 'failed' & reading aloud \\
\hline ma-žhuud & ma-žduuh & 'effort' & repetition \\
\hline faašil & šaafil & 'failing' & repetition \\
\hline bahr! & hbr (حير) & 'sea' & writing to dictation \\
\hline mi-nțaq-a & m-ṭq-t (مطنقة) & 'region' & writing to dictation \\
\hline naxl & xanl & 'palm trees' & picture naming (written) \\
\hline șahaa?if & șafaa?ih & 'newspapers' & picture naming (oral) \\
\hline
\end{tabular}

Two further aspects of ZT's metatheses are noteworthy. First, even if the linear order of consonants is affected, patterns and vowels usually remain intact in all tasks. The examples in (2) illustrate this point. The last two examples also involve phonemic or mapping errors, in addition to metathesis.

(2) Examples showing that patterns and vowels are unaffected

\begin{tabular}{|c|c|c|}
\hline Target & Output & Target gloss \\
\hline 2i-brịiq & Pi-qbiir & 'coffeepot' \\
\hline fanaažiin & fažaaniin & 'cups' \\
\hline fuhuus & fuṣuuh & 'examinations, scrutinies' \\
\hline hașsaad & șahhaad & 'harvester' \\
\hline hubul & hulub & 'ropes' \\
\hline ku?uus & kusuu? & 'glasses' \\
\hline laymuun & malyuun & 'lemon’ \\
\hline mu-xriž & mu-xžir & 'producer' \\
\hline ma-nșuub & ma-șnuub & 'set' \\
\hline ma-naazil & ma-laazin & 'houses' \\
\hline qubtaan & qutbaan & 'captain' \\
\hline šayaatiin & šataayiin & 'satans' \\
\hline ta-fahhus & ta-haffus & 'scrutiny' \\
\hline țarbuuš & țašbuur & 'hat' \\
\hline xanaaziir & xazaaniir & 'pigs' \\
\hline zirr & rịzz & 'button' 6 \\
\hline Saqaarib & Sanaaqib & 'scorpions' \\
\hline zarr-aat & zazr-aat & 'buttons' \\
\hline
\end{tabular}

\footnotetext{
${ }^{6}$ The word for 'rice' (rizz) is wholly emphatic whereas the word for 'button' (zirr) contains no emphasis.
} 
An overview of ZT's metatheses reveals that they all involve consonants only. The linear order of the vowel melody elements is never affected. In addition, ZT's metatheses target the consonants of the root only. Affixal consonants (in prefixes, suffixes, and infixes) are never involved, as shown in (3). ${ }^{7}$

(3) Examples showing that affixal consonants are not involved

\begin{tabular}{|c|c|c|}
\hline Target & Output & Target gloss \\
\hline Pih-t-imaal & Pih-t-ilaam & 'probability' \\
\hline fuqar-aa? & furaq-aa? & 'poor people' \\
\hline lawh-a & walh-a & 'picture, painting' \\
\hline ma-Paaðin & ma-daa?in & 'minarets' \\
\hline ma-hraž-aan & ma-ṛhaž-aan & 'festival' \\
\hline ma-laafiq & ma-Yaaliq & ‘spoons' \\
\hline ma-rekaz & m-krz (possibly ma-kraz) & 'center' \\
\hline ma-sbah & ma-ћbas & 'swimming pool' \\
\hline ma-žall-a & m-lž-t (possibly ma-lažž-a) & 'magazine' \\
\hline ma-žlis & m-lžs (possibly ma-lžis) & 'council, sitting room' \\
\hline mi-Sṭaf & mi-ṭ̂af & 'coat' \\
\hline mi-șmaar & m-mṣaar (possibly mi-msaar) & 'nail' \\
\hline mu-șhaf & m-șfh (possibly mu-sfah) & 'Holy Book' \\
\hline Pis-t-aitạf & Pis-t-aifat & 'begged' \\
\hline Pis-t-adraž & Pis-t-ažrad & 'led progressively' \\
\hline ?is-t-i?naaf & Pis-t-ifnaa? & 'appeal' \\
\hline șafh-a & șhf-t (possibly șahf-a) & 'page' \\
\hline șahaaf-a & ṣfaah-t (possibly ṣafaah-a) & 'media' \\
\hline ta-fahhas & t-ṣfr (possibly ta-ṣaffar) & 'examined'8 \\
\hline ta-laahum & ta-laamuh & 'solidarity' \\
\hline tilifuun & tfluun (possibly tifiluun) & 'telephone' \\
\hline ta-waqquf & ta-qawwuf & 'stopping' \\
\hline
\end{tabular}

Proximity to the edge of the word has no effect on access to the root. Regardless of the number of prefixes or suffixes, the consonantal root is the exclusive domain of metathesis, as shown in (4). The last example also displays a phonemic error.

\footnotetext{
${ }^{7}$ Only one exception was recorded (in the repetition task): ta-kaatub 'corresponding with each other' $\rightarrow$ ka-ta-atub. One similar error was also made in French (in the writing-to-dictation task): démuni (/de-muni/) 'impoverished' $\rightarrow$ medunis (see section 2.1.2).

${ }^{8} \mathrm{We}$ analyze this error as involving substitution of a root consonant rather than replacement of the whole root because (a) two of the three target root consonants remain unchanged, and (b) $\hbar$ and $r$ are close phonologically (both are sonorants and, when occurring together, they usually trigger emphasis, as in hibr ' ink').
} 
(4) Proximity to the edge of the word does not affect root consonant methathesis

\begin{tabular}{|c|c|c|}
\hline Target & Output & Target gloss \\
\hline ?a-ọrif-a & Pa-fộir-a & ‘envelopes’ \\
\hline Pa-rnab-aat & ?a-nrab-aat & 'rabbits' \\
\hline Sarž-aa? & Sažr-aa? & 'lame (FEM)' \\
\hline faraaš-aat & fašaar-aat & 'butterflies' \\
\hline ma--9aadin & ma-daafin & 'minerals' \\
\hline ma-Sbad & ma-@dab & 'temple' \\
\hline ma-fṛas-a & ma-rfas-a & 'stable' \\
\hline ma-lham-a & ma-hlam-a & 'butcher's shop' \\
\hline mi-țraq-a & mi-qtar-a & 'hammer' \\
\hline mu-s-t-aSmir & mu-s-t-amfir & 'colonizer' \\
\hline Pis-t-aițaf-naa & Pis-t-afțå-naa & 'we begged' \\
\hline Pis-t-ihdaaf & Pis-t-ifdaah & 'targeting' \\
\hline Pis-t-iraah-a & Pis-t-ihaar-a & 'pause' \\
\hline ya-yraq-uun & na-rqai-uun & 'they drown' \\
\hline
\end{tabular}

ZT's metatheses affect root consonants in verbs, nouns, and adjectives but, as we have just shown, they do not affect affixal consonants and vowels. ${ }^{9}$ In standard autosegmental representations, the root consonants and the vocalic morphemes are represented on separate tiers dominating a prosodic template, as are all affixes, including infixes such as $t$ - in $f$-t-axar 'boasted'. ZT's errors are compatible with autosegmental representations if we assume that only the root tier is subject to metathesis. As Arabic roots contain only consonants, it follows that only nonaffixal consonants will be affected by metatheses operating on the root tier. ${ }^{10}$

ZT produced only 12 metatheses in French, as shown in (5).

(5) All metathesis errors in French

\begin{tabular}{llllll}
\hline Target & & & Output & Target gloss & Task \\
\hline a. naval & [naval] & $\rightarrow$ & [vanal] & 'naval' & reading aloud \\
vanille & [vanij] & $\rightarrow$ & [valin] & 'vanilla' & reading aloud \\
éclipser & [eklipse] & $\rightarrow$ & [eplikse] & 'to eclipse' & repetition \\
démuni & [demuni] & $\rightarrow$ & medunis & 'impoverished' & writing to dictation \\
b. ballerine & [balrin] & $\rightarrow$ & [parlin] & 'ballerina' & repetition \\
c. plient & [pli] & $\rightarrow$ & [pile] & 'they fold' & reading aloud
\end{tabular}

${ }^{9}$ Although many stimuli contained infixes, ZT made only one error on an infixed word, in which the infix was not affected: Pih-t-imaal 'probability' and Pih-t-ilaam 'dreaming, having a wet dream'.

${ }^{10}$ Even radical glides that do not surface in some patterns (e.g., $w$ in /mawat/ $\rightarrow$ maat 'died') should be able to undergo root consonant reversal since we view metathesis as affecting the root tier. We have no data from ZT bearing on this prediction, but we interpret the near-synonymous root doublets $b w x / b x w, \hbar w q / q w \hbar, \hbar k w / k w h, t w\{/ \varsigma t w, \zeta w q / w \zeta q$ in (28) as evidence that it is borne out in the realm of diachrony. 


\begin{tabular}{|c|c|c|c|c|c|}
\hline d. pédalo & [pedalo] & $\rightarrow$ & palodé & 'pedal boat' & writing to dictation \\
\hline estomac & [estoma] & $\rightarrow$ & escamot & 'stomach' & writing to dictation \\
\hline e. darin & [darẽ $]$ & $\rightarrow$ & [dãri] & nonword & reading aloud \\
\hline agenda & [ažẽda] & $\rightarrow$ & angeda & 'agenda' & writing to dictation \\
\hline f. feuille & [fœj] & $\rightarrow$ & fueille & 'leaf' & writing to dictation \\
\hline goûter & [gute] & $\rightarrow$ & guote & 'to taste' & writing to dictation \\
\hline
\end{tabular}

We count all of these errors as metatheses but it is clear that only the five errors in $(5 a-b)$ are truly comparable to the Arabic ones. They involve metatheses between nonadjacent (5a) and adjacent (5b) consonants. The error in (5c) metathesizes a consonant and a vowel $(l$ and $i)$, whereas the ones in (5d) involve multiple reversals of consonants, vowels, or syllables, including that of the silent consonant $\langle\mathrm{c}\rangle$ in estomac. The two errors in (5e) involve movement of a nasal rather than metathesis stricto sensu. Finally, the two errors in (5f) are limited to vowels (gouter [gute] $\rightarrow$ guote 'to taste' and feuille [fœj] $\rightarrow$ fueille 'leaf'). In fact, they were both produced in writing and both involved the reversal of digraphs, $о u \rightarrow u o$ and $e u \rightarrow u e$, which actually left the target's phoneme order intact.

In addition to these qualitative differences, we observe a significant quantitative difference: the Arabic metatheses are much more numerous than the French ones (119 in Arabic and 12 in French) although the total number of stimuli used in testing ZT was almost the same: 1455 in Arabic and 1498 in French. There is a striking difference between the rates of metatheses in Arabic $(119 / 1455=8.18 \%)$ and French $(12 / 1498=.80 \%)$. And if we only include truly comparable errors, for French we must retain only the five errors in $(5 \mathrm{a}-\mathrm{b})$, which brings the error rates to $8.18 \%$ (Arabic) versus $.33 \%$ (French), that is, a proportion of 25 to 1 . The difference in the proportion of metathesis errors in the two languages is highly significant $\left(\chi^{2}=111, p<.0001\right)$.

2.1.3 A Morphological Explanation Let us consider possible explanations for the quantitative discrepancy between the two languages. We will argue that phonetic and graphemic rationales are unsatisfactory. As the impairment is the same in both languages, the differences must stem from the fact that the morphological units involved are different in Arabic and French.

Consider a phonetic account first. It cannot be claimed that ZT has phonetic problems with Arabic consonants because of perceptual or articulatory difficulties. Béland et al. (2000) have shown that he has no problems discriminating minimal pairs in both languages. Phonetics is clearly not involved because even the consonants common to both languages, that is, $/ \mathrm{t}, \mathrm{k}, \mathrm{b}, \mathrm{d}$, $\mathrm{f}, \mathrm{s}, \mathrm{z}, \breve{s}, \check{z}, \mathrm{~m}, \mathrm{n}, \mathrm{r}, \mathrm{l}, \mathrm{w}, \mathrm{y} /$, are metathesized in Arabic only. Furthermore, phonetics cannot explain why ZT targets radical consonants but not affixal ones in Arabic.

One might also argue that ZT's metatheses single out Arabic consonants because this language is written with consonant symbols only. Arabic short vowels are indicated by means of diacritics below or above letters but only under particular conditions (e.g., in the Quran and in schoolbooks intended for children or second language learners). Usually, only consonants and long vowels are written down. Thus, the salience of consonants in Arabic words could be taken to follow from their orthographic transcription. This explanation cannot be maintained, though, for four reasons. 
First, the graphemic explanation is invalid because ZT does not displace consonantal prefixes and suffixes even though they are also transcribed. Not only does he not move affixal consonants around but he does not even do this when they are homophonous with root consonants. The consonant of the prefix ma-, for instance, could be mistaken for a root consonant. In Arabic, roots abound whose first root element is $m$ (e.g., malaak 'angel', miskiin 'poor', maydaan 'field', miinaa? 'harbor'). Yet ZT spares prefixes even when they consist of consonants that could be radical, as shown in (6).

(6) Distinction between radical and affixal homophonous consonants

\begin{tabular}{|c|c|c|}
\hline Target & Output & Target gloss \\
\hline a. masah & samah & 'wiped' \\
\hline$\underline{\text { masaa? }}$ & smaa? (possibly samaa?) & 'evening' \\
\hline b. $\overline{\text { ma} a-z ̌ a l l-a ~}$ & $\underline{\text { m}-l z ̌ t ~}($ possibly $\underline{m a-l a z ̌ z ̌-a})$ & 'magazine' \\
\hline$\underline{\text { mu}}$-xriž & $\underline{\text { mu}}$-xžir & 'producer' \\
\hline
\end{tabular}

When $m$ is part of the root (6a), it can be metathesized, but when it belongs to a prefix (6b), it remains in situ. It is clear, then, that ZT runs a morphological scan to separate roots and affixes. He does not rely on spelling, since spelling does not separate stems and affixes in Arabic.

Is it possible, then, that $\mathrm{ZT}$ does not consider the graphemes of the whole word but only those of the window enclosing the vocalized stem? This cannot be the case either, because he metathesizes graphemes corresponding to consonants but not those corresponding to long vowels. As just mentioned, long vowels are always represented in Arabic script. As shown in (7), the symbols for $/ \mathrm{w} /\langle\mathrm{g}\rangle, / \mathrm{y} /\langle\nexists\rangle$, and $/ \mathrm{P} /\langle\boldsymbol{\langle}\rangle$ indicate length in $u u$, $i i$, and $a a$, respectively. (Recall that Arabic is written from right to left.)

(7)

\begin{tabular}{|c|c|}
\hline qur uu c & 'monkeys' \\
\hline kab ii r & 'big, large \\
\hline ðub aa $\mathrm{t}$ & 'flies' \\
\hline
\end{tabular}

Although long vowels are transcribed in the Arabic script, ZT does not metathesize them (e.g., $m a-$ žhuud 'effort' $\rightarrow$ ma-žzduuh, xanaaziiir 'pigs' $\rightarrow$ xazaaniiir). If he considered only the graphemes of the stem, he would move those of the long vowels along with those of the stem consonants.

Third, when ZT produces written metatheses, he respects the distribution of the allographs. Several Arabic letters adopt different shapes depending on their position in the letter string (e.g., $y$ is written $\langle\overrightarrow{\langle}\rangle$ word-initially, $\langle\exists\rangle$ word-medially, and $\langle ي\rangle$ word-finally). In writing $h b r$ (possibly

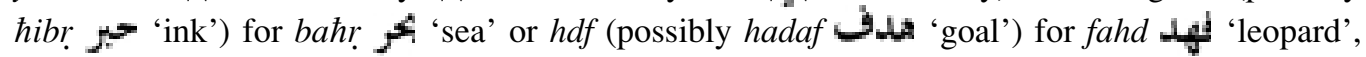
for instance, ZT spontaneously used the appropriate allographs. He does not move the symbols 
of the written form around, which shows that he does not manipulate the graphemic representation. If he did, he would not modify the shape of the letter to respect the writing conventions of the language. He would write $h d f$ as هدي instead of هدب

Finally, ZT's language impairments are not limited to tasks involving written input or output modalities. He also produces errors in spontaneous speech, oral picture naming, and repetition of nonwords, all tasks that do not involve mandatory written material. Hence, the problem cannot be due to the orthographic peculiarities of Arabic.

In the remainder of this article, we will show that ZT's consonant metatheses are identical to changes observed throughout Semitic in ludlings, slips of the tongue, and diachronic changes. Some of these Semitic languages transcribe all vowels (Classical Ethiopic, Amharic) or do not have a written tradition (most dialects of Arabic, all dialects of Gurage). This confirms our conclusion that orthography plays no role in root consonant metatheses.

The discrepancy in the error rate of metatheses between ZT's two languages could also be taken to result from an impaired morphological processing selectively affecting the Arabic grammar. This hypothesis is also ruled out because the distribution of his morphological errors is similar in his two languages. In Arabic, ZT was presented verb and adjective stimulus sets in an oral reading task to assess his ability to process derivational and inflectional morphological markers. In Arabic, he produced a total error rate of $98 / 120=82 \%$. In French, ZT was presented three stimulus sets in oral reading to test his ability to process derivational affixes and inflectional suffixes. The overall error rate in processing French affixed forms was $69 / 83=83 \%$. The two rates are almost identical and there is no significant difference between the error proportions in the two languages $\left(\chi^{2}=.007, p>.05\right)$.

Moreover, a qualitative analysis of ZT's morphological errors indicates that ZT is well aware of morphological boundaries in both languages because he always distinguishes homophonous syllables according to affixal or stem status. For instance, when reading insoumis [थ̃sumi] 'rebellious', ZT read soumis [sumi] 'obedient'. When shown the word sondage 'poll', which contains two morphemes, he read sonder, radio 'to poll, radio', which shows that he correctly analyzed

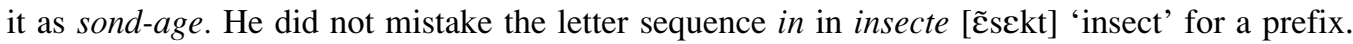
Instead of producing secte [sckt] 'sect', he made a semantic error and read the word as [mustik] 'mosquito'. When shown the word enquêter 'to investigate', which contains the base enquête 'inquiry', he read it as police 'police', showing that he did not mistake it for a derivation of the verb quêter 'to collect'. Other examples are given in (8) for French and (9) for Arabic.

(8) Morphological errors in French

\begin{tabular}{|c|c|c|c|c|c|}
\hline \multicolumn{2}{|l|}{ Target } & \multicolumn{2}{|l|}{ Target gloss } & \multirow{2}{*}{$\begin{array}{l}\text { Output } \\
\text { [fœj] }\end{array}$} & \multirow{2}{*}{$\frac{\text { Output gloss }}{\text { 'leaf, leaves' }}$} \\
\hline feuillage & [fœj-až] & 'foliage' & $\rightarrow$ & & \\
\hline refaire & [rə-fer] & 'redo' & $\rightarrow$ & [ro-fet] & 'redone (FEM)' \\
\hline recompter & [rə-kõt-e] & 'recount' & $\rightarrow$ & [kõt-e] & 'to count' \\
\hline tournent & [turn] & 'they turn' & $\rightarrow$ & [turn-e] & 'to turn' \\
\hline portillon & [port-ijõ] & 'gate' & $\rightarrow$ & [port] & 'door' \\
\hline
\end{tabular}


(9) Morphological errors in Arabic

\begin{tabular}{lllll}
\hline Target & Target gloss & & Output & Output gloss \\
\hline Pa-zhaar & 'roses' & $\rightarrow$ & zahr & 'rose (GENERIC)' \\
xaal-a & 'maternal aunt' & $\rightarrow$ & xaal & 'maternal uncle' \\
žamiil-a & 'beautiful (FEM)' & $\rightarrow$ & žamiil & 'beautiful (MASC)' \\
ma-ktab & 'desk, office' & $\rightarrow$ & kitaab & 'book' \\
ma-qbar-a & 'graveyard' & $\rightarrow$ & qabr & 'grave' \\
r-t-afa؟ & 'rose (veRB)' & $\rightarrow$ & rafå & 'raised (vERB)' \\
h-t-afal & 'celebrated (VERB)' & $\rightarrow$ & hafl-a & 'party' \\
\hline
\end{tabular}

Examples of this type abound for prefixes and suffixes in Arabic and French. Because ZT's processing of inflectional and derivational affixes is impaired in both languages, the disparity in the error rate of metatheses between his two languages cannot be caused by an impaired processing of affixed forms that would be specific to his Arabic mental grammar. It must follow from some deeper impairment that is common to both languages but is manifested only in Arabic.

We submit that ZT's errors single out Arabic consonants because they form a unit in his mental lexicon. That unit is not phonetic/phonological, since he leaves affixal consonants in place. In accessing radical consonants, ZT also identifies affixes, as evidenced by the data in (9). However, what he separates the affixes from cannot be a vocalized stem since he manipulates only the consonants of the stem, something he does not do in French. The set of consonants that he does metathesize in Arabic coincides with the morphological unit traditionally known as the root. He makes significantly fewer errors of this type in French than in Arabic because these two languages have different morphological representations: stem consonants do not form distinct morphemes in Indo-European languages, which makes these changes less natural (though not impossible). In section 4, we will elaborate on the consequences of this morphological explanation and rule out phonological explanations based on phonotactic and syllabic constraints.

2.1.4 Lack of Phonological and Semantic Motivation As a typical output deep dyslexic, ZT has problems with speech production and more specifically with phonological planning, but he has no semantic disorder. It is clear that his metatheses are output errors. If ZT's competence were affected, that is, if he had lost all information pertaining to the order of root consonants, he would misunderstand words containing identical root consonants in different orders, such as the verbs $k a t a b$ 'wrote' and kabat 'repressed'. However, he makes no such confusions at the input processing level, that is, comprehension. Moreover, although his metatheses are frequent, they still form a small percentage of his production: most of his words show appropriately ordered consonants. Both characteristics are incompatible with actual loss of underlying order in his root entries.

The lexical entries of roots contain information of a syntactic, semantic, morphological, and phonological nature. The last is divided between segmental features, which encode place and manner makeup, and ordering information, which encodes precedence relations. ZT has problems with precedence relations. We suggest that his root entries are ordered correctly in UR but he 
has difficulties either mapping root consonants to the template or keeping them in the proper order during speech production.

As far as can be determined from our limited database, ZT's metatheses are not predictable from phonological properties (such as manner or place features, sonority, or perceptibility of the type invoked by Hume (1998b) for normal metatheses) or morphological ones (such as verb classes or lexical categories). All consonants can be moved, sometimes with two or even three wrong outputs for the same root, as shown in (10).

(10) Examples showing that the same input can have several outputs

\begin{tabular}{|c|c|c|c|c|c|}
\hline Root & Target & Output 1 & Output 2 & Output 3 & Target gloss \\
\hline \multirow{4}{*}{$\begin{array}{l}\text { ðorf } \\
\text { sqf } \\
\text { zhr }\end{array}$} & Pa-ọrif-a & Pa-fọir-a & 2a-ọfir-a & & 'envelopes' \\
\hline & ?u-squf & ?u-fqus & ?u-qsuf & & 'bishop' \\
\hline & zahr & hzr (possibly hazr) & & & 'rose' \\
\hline & Pa-zhaar & & Pa-zraah & & 'roses' \\
\hline \multirow{6}{*}{$\begin{array}{l}\mathrm{b}(\mathrm{w}) \mathrm{xr} \\
\text { bỵ̣ } \\
\text { Sṭ̣ }\end{array}$} & baaxir-a & baarix-a & & & ‘ship’ \\
\hline & bawaaxir & baraaxiw & baxaarib & baxaawir & 'ships' \\
\hline & buyḍ & yadab & buḍ & & 'hatred'11 \\
\hline & mu-s-t-âțif & mu-s-t-aifit & & & $\begin{array}{l}\text { 'begging } \\
\text { (ADJ)' }\end{array}$ \\
\hline & Pis-t-iYțaaf & & Pis-t-ifțaa؟ & & $\begin{array}{l}\text { 'begging } \\
\text { (NOUN) }\end{array}$ \\
\hline & Pis-t-aSțaf-naa & Pis-t-aifat & Pis-t-afțai-naa & & 'we begged' \\
\hline
\end{tabular}

These examples indicate that any reordering of root consonants seems possible. Reordering could conceivably be governed by phonological or perceptual factors, but a larger body of data would be needed to identify them. However, even if such factors were at work, they would not affect our argument in favor of the lexical status of the root. As long as the root constitutes the exclusive domain of consonant reversals, it must be treated as an independent morphological unit.

It is also crucial to test if ZT's metatheses are predictable on semantic grounds because, as mentioned in section 2.1.1, lexical confusion within semantic fields is the hallmark of output deep dyslexia, such as uttering fork when shown the word knife (or when shown a knife). Consequently, it is conceivable that ZT would metathesize consonants not because of a phonological problem but because he is pronouncing a semantically related word that happens to contain the same consonants ordered differently. As we will show in section 4.1, Arabic has a number of such synonymous roots whereas French does not. However, as we will show here, ZT's errors are actually not prompted by semantic confusion.

From the point of view of meaning, ZT's errors can be divided into three categories. First are those outputs that happen to be existing words, as in (11). The last two examples also exhibit a phonemic error.

\footnotetext{
${ }^{11}$ Output 1 of this word also involves a template misselection.
} 
(11) Metatheses in which outputs are existing words

\begin{tabular}{|c|c|c|c|}
\hline Target & Target gloss & Output & Output gloss \\
\hline daxal & 'entered' & xadal & 'became numb' \\
\hline ð̣arf & 'envelope, situation' & ðִafr & 'victory' \\
\hline fahas & 'examined, scrutinized' & fașah & 'was fluent' \\
\hline ma-dxal & 'entrance' & xadal & 'became numb' \\
\hline nabat & 'grew' & bint & 'daughter' \\
\hline qird & 'monkey' & qidr & 'cooking pot' \\
\hline ta-zalzal & 'shook (of earth)' & ta-lazlaz & 'was tired, shaken' \\
\hline șafh & 'forgiveness' & șhb (possibly șahb) & 'friends' \\
\hline qaws & 'arch' & swt (possibly sawt) & 'stripe, whip' 12 \\
\hline
\end{tabular}

Examination of all of ZT's errors reveals no semantic association between target and output. In some cases (e.g., ta-zalzal $\rightarrow$ ta-lazlaz), the output is a rare word, so we suspect that it is only by chance that the output happens to coincide with a real word.

The second category of errors comprises outputs that are nonwords but whose consonants form an existing root, as in (12). Again, there is no semantic relationship between the target and the output root.

(12) Metatheses in which outputs contain an existing root

\begin{tabular}{|c|c|c|c|c|}
\hline Target & Gloss & Output & $\begin{array}{l}\text { Existing } \\
\text { word }\end{array}$ & Gloss \\
\hline Pa-saatið-a & 'teachers' & Pa-saadis-a & sudus & 'one-sixth' \\
\hline Pa-wqaaf & $\begin{array}{l}\text { 'religious } \\
\text { properties' }\end{array}$ & Pa-wfaaq & wifaaq & 'agreement' \\
\hline fa?r & 'rat' & far? & firaa? & 'fur' \\
\hline faras & 'mare' & fasar & fassar & 'explained' \\
\hline fușh-aa & 'standard speech' & șufh-a & șafh-a & 'page' \\
\hline ma-sžid & 'mosque' & ma-ždis & žaadis & 'hard' \\
\hline ma-tžar & 'store' & ma-žtar & žatr & 'tent' \\
\hline mi-liaq-a & ‘spoon’ & mi-Slaq-a & Saaliq & 'hanging' \\
\hline nidaa? & 'call' & dinaa? & duny-aa & 'earthly life' \\
\hline nuṭq & 'pronunciation' & nuqt & nuqt-a & 'drop (water), dot' \\
\hline quruud & 'monkeys' & quduur & qadar & 'destiny' \\
\hline Pis-t-a?naf-naa & 'we appealed' & Pis-t-afne? & fanaa? & 'end' \\
\hline
\end{tabular}

${ }^{12}$ On many occasions, ZT substitutes the emphatic $t$ for the uvular $q$, which is why we interpret this example as a metathesis of $q$ and $s$. We have also observed this substitution in Moroccan Arabic child language (e.g., suq $\rightarrow$ sut 'market'). It is also reported in allophonic changes in Zway Gurage (Ethiopic), for example, ak' nabə versus $t$ ' ambe bala 'to listen', and in Qabenna (Cushitic), for example, k'amájjo versus t' amájjo? 'to put the yoke' (Leslau 1992:600). Ethiopic and Cushitic emphatics are glottalized, unlike the pharyngealized emphatics of Arabic, but the two sets are cognate. 


\begin{tabular}{|c|c|c|c|c|}
\hline saqf & 'roof' & faqs & faqas & 'died, hatched' \\
\hline saxaa? & 'generosity' & xasa & xasa? & 'chased away' \\
\hline tiby & 'tobacco' & tiyib & tayib & 'perished' \\
\hline wažas & 'was afraid' & žawas & žaas & 'peered, pried' \\
\hline žinh & 'wing' & žiłn & žahan & $\begin{array}{l}\text { 'fed (TRANS) } \\
\text { poorly' }\end{array}$ \\
\hline zaraaf-a & 'giraffe' & zafaar-a & zafr-a & 'sigh’ \\
\hline zaraaf-a & 'giraffe' & $\begin{array}{l}\text { zfraa-t (possibly } \\
\text { zafraa- } t \text { ) }\end{array}$ & zafr-a & 'sigh' \\
\hline hamq-aa? & 'crazy (FEM)' & haqm-a & haqm & 'kind of pigeon' \\
\hline Pa-žfaan & 'eyelids' & ?a-šbaan ${ }^{13}$ & šaban & 'was fat' \\
\hline
\end{tabular}

In psycholinguistics, the errors in (11) and (12) are said to be lexically biased because one cannot rule out that they are prompted by phonological similarities, that is, analogy, between the target and the output forms.

The third category comprises lexically unbiased errors: these form neither words nor roots in Arabic, as in (13). Semantic motivation is out of the question for these outputs since they have no meaning. The last example also exhibits a phonemic error.

(13) Metatheses in which outputs are nonwords and nonroots

\begin{tabular}{|c|c|c|}
\hline Target & Gloss & Output \\
\hline ?iөyuubyaa & 'Ethiopia' & Rabyuu $\theta$ yaa \\
\hline bå日ar & 'scattered' & bạra $\theta$ \\
\hline baayiḍ & 'hating' & baaḍiy \\
\hline biid & 'eggs' & diib \\
\hline ruias-aa? & 'presidents' & rusa2-aa? \\
\hline darrạǎž-a & 'bicycle' & dažraaž-a \\
\hline
\end{tabular}

We conclude that ZT's metatheses are not caused by confusion between lexical entries that are semantically related. They are due either to an inability to consistently maintain the underlying order of root consonants during phonological derivation and speech production or, for lexically biased errors, to confusion between roots whose segmental makeups happen to be similar. We address the issue of lexical bias in section 4.1.

\subsection{Metathesis in Ludlings}

ZT's errors have no parallel in normal phonological processes. To begin with, productive metatheses of nonadjacent consonants are very rare. We know of three instances: the Akkadian infix -t-

\footnotetext{
${ }^{13}$ This error seems to involve a metathesis of the feature [voice] between $\check{z}$ and $f$, with $z \rightarrow \check{s}$ and $f \rightarrow v \rightarrow b$ because Arabic has no /v/.
} 


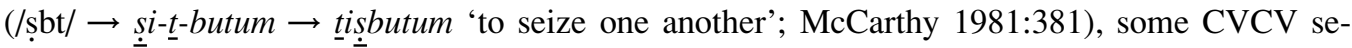

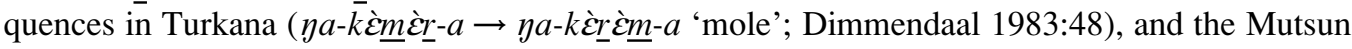

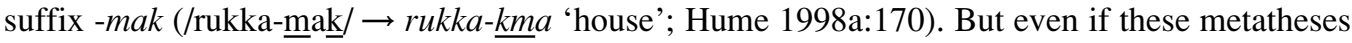
were more frequent, ZT's errors would still be unparalleled in normal phonological processes because they involve random reversal of tautomorphemic consonants over intervening consonants. Changes of this type are attested only in occasional diachronic changes. ${ }^{14}$ We will show in section 4.1 that such phenomena are in fact common in Semitic, but only on an unproductive and diachronic basis. On a productive basis, such phenomena exist only in ludlings, that is, language games, and slips of the tongue. Indeed, ZT's errors are identical to ludlings that exist only in Semitic.

Bagemihl's $(1988,1989)$ survey of ludlings shows that reversal processes of all kinds, including even mirror-image reversals, are very common except for one type: permutation. This reversal process, in which many or all of the possible root consonant reorderings are attested, has been reported for ludlings in two languages: Bedouin Hijazi Arabic and Moroccan Arabic. Examples from the former (Al-Mozainy 1981:86, McCarthy 1982:197) and the latter (Heath 1987:184) ludlings are given in (14) and (15), respectively. In (14), all five possible reorderings of the three root consonants are attested: $123 \rightarrow\{321,213,231,312,132\}$. Following Berg and Abd-ElJawad's (1996) terminology, we call orderings in which two consonants are displaced (i.e., 321, 213, and 132) bipartite and orderings in which three consonants are displaced (i.e., 231 and 312) tripartite. The same distinction will be applied to ZT's errors in section 4. In (15), 4 of the 23 possible reorderings of four consonants are reported: $1234 \rightarrow\{2413,3142,4123,4321,1324$, 1243 , etc. $\}$.

(14) Ludlings involving root consonant reorderings in Bedouin Hijazi Arabic

\begin{tabular}{lcllll}
\hline Regular form & \multicolumn{3}{c}{ Regular form } & \multicolumn{3}{c}{ Regular form } \\
\hline $\begin{array}{l}\text { kattab } \\
\text { 'caused to write' }\end{array}$ & 123 & $\begin{array}{l}\text { s-t-aslam } \\
\text { 'surrendered' }\end{array}$ & 123 & $\begin{array}{l}\text { ž-t-imå } \\
\text { 'met' }\end{array}$ & 123 \\
$\begin{array}{l}\text { Game forms } \\
\text { battak }\end{array}$ & 321 & s-t-amlas & 321 & S-t-imaž & 321 \\
takkab & 213 & s-t-alsam & 213 & m-t-ižå & 213 \\
tabbak & 231 & s-t-almas & 231 & m-t-åaž & 231 \\
bakkat & 312 & s-t-amsal & 312 & S-t-ižam & 312 \\
kabbat & 132 & s-t-asmal & 132 & ž-t-åam & 132 \\
\hline
\end{tabular}

\footnotetext{
${ }^{14}$ Examples include the pronunciations of English to remunerate as to renumerate (probably by analogy with to enumerate and numerous), as well as those of French hypnotiser 'to hypnotize' and asphyxier 'to asphyxiate' as hynoptiser and axphysier. Some metatheses have become standard, as in French moustique 'mosquito' (from Spanish mosquito, by analogy with French tique 'tick'). Some changes involve movement of a consonant rather than metathesis proper, as in popular French infractus 'infarct' and aréoport 'airport' for Standard French infarctus and aéroport. Blevins and Garrett (1998:525-527) discuss similar instances of liquids, pharyngeals, and glottals moving across words.

${ }^{15}$ The first $a$ of this vocalic pattern is raised to $i$ when it stands in an open syllable and is not immediately followed by a guttural consonant, liquids, or $n$ (Al-Mozainy 1981:57).
} 
(15) Ludlings involving root consonant reorderings in Moroccan Arabic

\begin{tabular}{ll}
\hline Regular form \\
\hline $\begin{array}{l}\text { krmuṣ-a } \\
\text { 'fig' }\end{array}$ & 1234 \\
Game forms & \\
ṛșum-a & \\
mkșur-a & 2413 \\
șkṛum-a & 3142 \\
șmṛuk-a & 4123 \\
\hline
\end{tabular}

In Bagemihl's analysis, the only way to derive the reversals in (14) and (15) is to posit a context-free consonant exchange rule. If one assumes, as does Bagemihl, that only maximum and minimum crossing of association lines is allowed, ${ }^{16}$ the reversal involved in the transformation of $\check{z}$-t-ima $\{$ (123) into $S$-t-imaž (321) requires one step: maximum crossing, that is, exchange between $\check{z}$ and $S: \check{z}$-t-ima $S \rightarrow\{$-t-imaž. In the same ludling, the reversal involved in the transformation of $\check{z}$-t-ima $(123)$ into $m$-t-aSaž (231) requires at least two steps: (a) minimum crossing, that is, exchange between $\check{z}$ and $m: \check{z}$-t-ima $\rightarrow m-t-i \check{z} a S$, and (b) minimum crossing, that is, exchange between $\check{z}$ and $S: m-t-i \check{a} a S \rightarrow m-t-a S a \check{z}$. In Bagemihl's view, these ludlings are marked in two respects: (a) the exchange rule is not specified with respect to the environment in which it applies (the first and the third consonants in the first example and all three consonants in the second one), and (b) the exchange rule can be applied with either the maximum or the minimum crossing parameter setting. If we limit the crossing parameter to one setting, the first example can be derived with recursive minimum crossing only: (a) exchange between $m$ and $S: \check{z}$-t-ima $\rightarrow \check{z}$-t $a \oint a m$, (b) exchange between $\check{z}$ and $S: \check{z}$-t-aSam $\rightarrow\{$-t-ižam, and (c) exchange between $\check{z}$ and $m$ : $\{$-t-ižam $\rightarrow\{$-t-imaž. Yet, for Bagemihl (1989), these consonant exchanges would still be marked not because of the recursiveness, as this is also needed for other ludlings, but because the derivation of the Arabic game forms requires more than one application of the same reversal process (consonant exchange). Other ludlings involving more than one reversal process in the derivation of a game form combine different types of reversal (e.g., syllable reversal is combined with consonant exchange in Burmese).

Let us note, however, that it is entirely accidental for permutation to be limited to dialects of Arabic. Bagemihl's account leads one to expect that random consonant reorderings should be equally likely outside of Semitic.

Arabic ludlings typically metathesize root consonants only, leaving all affixes unaffected. This is parallel to ZT's metatheses. Arabic ludlings also illustrate the psychological reality of

\footnotetext{
${ }^{16}$ With respect to consonantal roots, crossing is minimum when the switched consonants are adjacent (e.g., $123 \rightarrow$ 213) because as few association lines as possible are crossed. Crossing is maximum when the switched consonants are first and last (e.g., $123 \rightarrow 321$ ) because as many association lines as possible are crossed.
} 
roots, but we believe that aphasic errors (and, as we will show in the next section, slips of the tongue) constitute a more compelling source of external evidence than ludlings do because they are not taught and are not subject to voluntary mental computations. Naturally, an analysis correlating random metathesis with an independent property of the language (here root-and-pattern morphology) is a priori desirable, but chance and cultural diffusion cannot be ruled out. Just as we do not consider that an unwritten language would not lend itself to writing, we cannot conclude from the absence of random reversals outside of Semitic that non-Semitic languages would not lend themselves to such ludlings. The only way to prove the existence of a correlation would be to teach randomly metathesizing ludlings to two groups of speakers under identical conditions and show that Semitic speakers learn them more easily than non-Semitic speakers do. We suspect that the results would be conclusive, but to our knowledge, such tests have never been conducted. In ZT's case, no doubt can be entertained because he was never shown, let alone taught, these segment reversals. The fact that he produces this specific pattern of errors without prompting and applies it only in Arabic reveals a deep-seated difference in the mental representations of his two languages.

\subsection{Metathesis in Slips of the Tongue}

Aphasic errors are more comparable to slips of the tongue than to ludlings because they are equally involuntary and free of instruction. Berg and Abd-El-Jawad (1996) examined consonant reversals in Jordanian Arabic and German, based on their own corpora, as well as consonant reversals in English, based on Stemberger's (1983) and other corpora. They observed that Jordanian Arabic and Germanic (German/English) errors display different properties.

First, only Arabic speakers produce tripartite reversals. Berg and Abd-El-Jawad excluded these errors from their study because of their focus on errors common to Arabic and Germanic, but this explicit mention adds a fourth instance to the random metatheses already noted in Bedouin Hijazi Arabic, Moroccan Arabic (ludlings), and Standard/Lebanese Arabic (ZT).

Second, they note that Germanic slips are sensitive to a (syllabic) Positional Constraint, whereby substitutions normally involve like syllabic constituents, that is, onset for onset or coda for coda (e.g., pessimistisch [pesi:mıstı̌̌] 'pessimistic' $\rightarrow$ [pesi:mıštıs]). On the other hand, their Arabic slips are insensitive to this constraint (e.g., gurf-a 'room' $\rightarrow$ ru $u$ ff-a). If we assume that this difference is due to underlying preanchoring (Germanic segments being preanchored whereas Arabic segments are unanchored because of nonconcatenative morphology), we have a rationale for why onset-coda metatheses are limited to Arabic because, in this language, floating consonants can be attached to either onset or coda depending on the template. If underlying floating root consonants are responsible for the irrelevance of the Positional Constraint in Arabic slips of the tongue, all root consonant metatheses - aphasic errors, ludlings, and slips of the tongue-have to take place before mapping since they leave vowels and infixes unaffected. Note however, that this explanation holds only if URs include root consonants on a tier other than that of templates and affixes (including aspectual vowels). If they included only fully formed words or vocalized 
stems, there would be no explanation for why Arabic consonants alone are insensitive to syllabic positions. We will suggest in section 4.1.1 that this lack of preanchoring is also responsible for why metatheses are more frequent in ZT's Arabic than in his French. ${ }^{17}$

Recourse to floating root consonants also provides a better explanation for why randomly metathesizing ludlings are also limited to Arabic than do Bagemihl's recursive segment reversals because, as mentioned in the previous section, recursiveness does not correlate with any independent property of Arabic, whereas the absence of preanchoring does.

In this section, we have discussed both new and previous external evidence for the morphemic nature of Arabic roots. Recent external evidence for Semitic roots is also presented by Feldman, Frost, and Pnini (1995) and Frost, Deutsch, and Forster (1997), based on root priming in lexical decision and naming in Modern Hebrew, as well as by Davis and Zawaydeh (1999) and Zawaydeh and Davis (1999), based on hypocoristics in Jordanian Arabic.

\section{External Evidence for Templates}

Templates are central to most accounts of Semitic morphology. All morpheme-based theories form words by combining roots and templates whereas most word-based theories combine stems and templates. We have reviewed external evidence for roots from metatheses in aphasic speech, ludlings, and slips of the tongue. We will now show that template misselection errors from aphasic speech, ludlings, and slips of the tongue also provide external evidence for templates. In spite of this parallel typology of evidence, metatheses are intrinsincally different from template misselections because reversing root consonants is a phonological operation whereas selecting the wrong template is a morphological one.

\subsection{Template Misselection in Aphasic Speech}

If errors can target morphemes, we also expect to find aphasics who make errors with the other morphemes making up a Semitic word, such as templates. ZT produces such errors. For instance, instead of waasi 'wide', he produced wasiiא, which is a nonword using the template of kabiir 'big'. We will not base our discussion of template misselection on ZT's performance because his errors often also involve metatheses (e.g., waasi $-a$ 'wide (FEM)' $\rightarrow$ waSiis, a nonword) and/or affix stripping (i.e., deletion of affixes; e.g., xaal-a 'maternal aunt' $\rightarrow$ xaal 'maternal uncle'). Instead, we will discuss evidence from an aphasic speaker whose errors are more straightforwardly interpretable because they are, for the most part, confined to template misselection. Barkai (1980) presents a case study of a young Israeli agrammatic aphasic patient, Dudu, who suffered traumatic

\footnotetext{
${ }^{17}$ Berg and Abd-El-Jawad (1996:314) claim that Arabic slips of the tongue occur after root consonants have been mapped to the template. As far as we can see, their motivation for not invoking the floating nature of root consonants is that their data display more errors involving adjacent consonants (e.g., $k$ and $t$ in $a k t a b$ ) than nonadjacent ones (e.g., $k$ and $t$ in katab). In our view, there are more metatheses in Arabic than in Indo-European because consonants float before they are mapped to the template. At this early stage, Arabic consonants are more prone to metathesis than are IndoEuropean consonants. Once Arabic consonants have been mapped to the template, the usual preference to metathesize adjacent consonants holds in Arabic, as it does in other languages. Consequently, Arabic consonants have two configurations under which they can metathesize: before and after they have been anchored. Indo-European consonants have only the latter configuration.
} 
brain damage and subsequently developed verbal pattern errors in his mother tongue, Modern Hebrew. Unlike ZT, Dudu does not make errors on roots.

We illustrate in (16) the verbal patterns of Modern Hebrew with xašav 'to think'.

(16) Verbal patterns of Modern Hebrew

\begin{tabular}{|c|c|c|c|c|c|}
\hline & & Past & Present & Future & Gloss \\
\hline Pattern 1 & (pa'al) & xašav & xošev & yaxšov & 'to think' \\
\hline Pattern 2 & (nif'al) & nexšav & nexšav & yexašev & 'to be thought/considered' \\
\hline Pattern 3 & (pi'el) & xišcv & mexašcv & yexašev & 'to calculate/compute' \\
\hline Pattern 4 & (pu'al) & xušav & mexušav & yexušav & passive of verbal pattern 3 \\
\hline Pattern 5 & (hif'il) & hexšiv & maxšiv & yaxšiv & $\begin{array}{l}\text { 'to consider/appreciate/ } \\
\text { respect' }\end{array}$ \\
\hline Pattern 6 & (huf'al) & huxšav & muxšav & yuxšav & passive of verbal pattern 5 \\
\hline Pattern 7 & (hitpa'el) & hitxašev & mitxašev & yitxašev & $\begin{array}{l}\text { 'to be considerate to/take } \\
\text { into account' }\end{array}$ \\
\hline
\end{tabular}

As is the case for verbs in other Semitic languages, every Modern Hebrew verb can be conjugated in every tense but it is exceptional for a verb to select all patterns. This is why tenses are regarded as inflectional and patterns as derivational (see Aronoff 1994). The two verbs in (17) illustrate the fact that different verbs select different sets of verbal patterns.

(17) Patterns selected by two Modern Hebrew verbs

\begin{tabular}{llll}
\hline & & šavar 'to break' & tikcn 'to repair' \\
\hline Pattern 1 & (pa'al) & šavar & - \\
Pattern 2 & (nif'al) & nišbar & - \\
Pattern 3 & (pi'el) & - & tiken \\
Pattern 4 & (pu'al) & - & tukan \\
Pattern 5 & (hif'il) & - & hitkin \\
Pattern 6 & (huf'al) & - & hutkan \\
Pattern 7 & (hitpa'el) & - & - \\
\hline
\end{tabular}

As a consequence, the lexical information of any given verb must include not only its root consonants but also the largely idiosyncratic list of patterns it can select. In the mental lexicon, the lexical entry of a verb includes at least its semantic field, its root consonants, and the check marks indicating which patterns it selects. Even the composite meaning that a verb takes on when combined with a given pattern is often partly idiosyncratic. For instance, a comparison of Arabic $k a t a b$ 'wrote' and $k$-t-atab 'subscribed' with našar. 'spread (TRANS)' and $n$-t-ašar. 'spread (INTRANS)' reveals that they are parallel morphologically (verbal pattern 1 vs. verbal pattern 9) but not semantically. This is comparable to the observation that English re- does not make the same semantic modification to the stems shape and turn in to reshape and to return.

Dudu's errors typically leave the root consonants intact. He makes mistakes in producing 
either patterns that are well formed for a given verb but are inappropriate syntactically, or patterns that are nonoccurring for that verb. In the first case, he matches the verb with the pattern that it would select in a different context. To illustrate this on the basis of Arabic, this first type of error would involve confusions between actual verbal patterns such as verbal pattern 1 katab 'wrote', verbal pattern 3 kaatab 'corresponded', and verbal pattern $9 k$-t-atab 'subscribed'. Comparable errors in English would involve confusions between verbs of the same derivational family, such as cover, uncover, discover, and recover. In the second case, Dudu matches the verb with a pattern that it cannot select, thereby filling lexical gaps. In Arabic, this would involve producing verbal pattern $9 * q$-t-ara? instead of verbal pattern 1 qara? 'read'. Although * $q$-t-ara? would presumably be well formed and mean 'read (MIDDLE)' (as in 'this book reads easily'), it simply does not exist. Comparable errors in English would consist in creating verbs such as unread, subread, or disread when meaning read. Some of Dudu's errors are shown in (18).

(18) Errors produced by the aphasic patient Dudu (Barkai 1980)

\begin{tabular}{lllll}
\hline Correct form & Pattern & Gloss & Output & Pattern \\
\hline ləvate & 3 & 'to pronounce' & livto & 1 (nonoccurring) \\
šalax & 1 & 'he sent' & šileax & 3 (nonoccurring: archaic) \\
yisog & 2 & 'he will retreat' & yasug & 1 (nonoccurring) \\
yišbəru & 1 & 'they will break' & yišavru & 2 (occurring) \\
yəfutru & 4 & 'they will be dismissed' & yipatru & 2 (occurring) \\
higdilu & 5 & 'they enlarged' & gadlu & 1 (occurring) \\
higati & 5 & 'I arrived' & hagati & 1 (nonoccurring) \\
tibahalu & 2 & 'you will be shocked' & tivhalu & 1 (nonoccurring) \\
\hline
\end{tabular}

As his productions are either occurring but contextually inappropriate or nonoccurring but formally correct, it appears that Dudu has trouble accessing the selection part of his verb entries. He misplaces the check marks that belong to a given verb but not the consonants of the root. ${ }^{18}$ Some examples of pattern misselections in Hijazi Arabic agrammatic speech can also be found in Safi-Stagni 1991:261, 1995:102.

Recall that autosegmental representations of Semitic stems include three levels: the root, the template, and the vocalic morpheme(s). We have just noted that aphasic errors can affect the root alone, the template alone, or the template together with vowels. We would also expect to find errors that affect the vocalic morpheme(s) only (producing, for example, kutib $\rightarrow$ kitub or katub), but we know of no clear examples in the literature other than the Amharic tongue twister to be discussed in section 3.3, and ZT did not produce any. This gap in error patterns may be due either to the fact that at present there are insufficient data on Semitic aphasiology or, as we suspect, to

18 Theories in which affixes select stems must claim that verbal patterns select roots, rather than the reverse (see Borer 1991:136). In such theories, it is the verbal pattern that includes idiosyncratic check marks stating what roots it selects. The interpretation of Dudu's linguistic deficit in this perspective would be that he has difficulty accessing the check marks in the subcategorization frames of his verbal patterns. Under both views, however, his problem seems to be an impaired access to subcategorization features. 
the fact that autosegmental representations are not divided into three equal parts. The relationship between the pattern and the vocalic morpheme(s) is much closer than that between either of them and the root. This is why Dudu typically manipulates patterns and vowels together. In fact, there is little evidence that vocalic morphemes are mapped to templates in the way root consonants are. They may well be prelinked to templates, as in Guerssel and Lowenstamm's (1996) and Idrissi's (1997) treatments of Arabic verbs and nouns, respectively, and Idrissi's (2000) treatment of Berber nouns. So it is possible that templates and vocalic morphemes form a morphological subconstituent in the way most analyses assumed prior to the introduction of autosegmental representations.

Another observation we can make is that errors seem to be of two kinds: (a) creating a new root by changing the order of consonants (ZT's errors), or (b) selecting another template (Dudu's and some of ZT's errors). There seem to be very few errors in which new, nonexistent templates are created. This may reflect a strong tendency to produce possible words (i.e., words that may or may not exist but that obey the morphophonological constraints of the language). Clearly, though, these are early conclusions. Understanding the mechanics of template misselection will require, among other types of evidence, more descriptions of aphasic patients such as Dudu and ZT.

Given autosegmental representations, we should observe manipulations of the prosodic constituents of the template, such as syllables or moras. Errors that could be construed as involving syllable reversal were indeed occasionally produced by ZT: for example, $\left.\left(_{\sigma} \mu \mu\right)\left(_{\sigma} \mu\right) \rightarrow{ }_{\sigma} \mu\right)$ $(\sigma \mu \mu)$, as shown in (19).

(19) Apparent examples of syllable reversals

\begin{tabular}{lll}
\hline Target & Gloss & Output \\
\hline a. waasi & 'wide' & wasii \\
waasii-a & 'wide (FEM)' & waSiiis \\
haliib & 'milk' & haalib \\
b. Pa-țibb-aa? & 'physician' & Pa-țib-aa? \\
hams & 'whispering' & mhas \\
\hline
\end{tabular}

However, we think it more plausible that the errors in (19a) result from template misselection, rather than syllable reversal, since both input $\mathrm{CaaCiC}$ and output $\mathrm{CaCiiC}$ exist in the language. By contrast, the first error in (19b) cannot be due to template misselection since this output pattern does not exist in Arabic with initial gemination, though it is attested with an initial cluster, as in ?a-șdiq-aa? 'friends'. On the other hand, the pattern of the second error in (19b) is unknown in Arabic.

\subsection{Template Misselection in Ludlings}

There are ludlings comparable to Dudu's template errors just as there are some that are comparable to ZT's root errors. Some pattern transfers are observed in Semitic ludlings that map a verb to a 
verbal pattern that is contextually or lexically inappropriate. This is the case with the Gogot Gurage ludlings illustrated in (20a-d), from Leslau 1992:526ff. The shapes and functions of these verbal patterns are discussed by Chamora (1996), Lowenstamm (1996), Prunet (1996, 1998), Rose (1997), Banksira (2000, to appear), and Prunet and Chamora (to appear). Verbs are incorrectly mapped to the frequentative pattern in (20a) and to the compound verb pattern in (20b). In (20c), a consonant is added to a triliteral verb, which is then mapped to the pattern of quadriliteral verbs. In (20d), a verb is nominalized by mapping it to an inappropriate pattern, and an adjective is mapped to the wrong pattern.

The ludling illustrated in (20e) maps Amharic words to a pattern that does not exist in the standard language (see Demisse and Bender 1983, McCarthy 1984).

(20) Template misselection in Gurage and Amharic ludlings

\begin{tabular}{llll}
\hline Input & Gloss & & Ludling form \\
\hline a. kənna-m & 'he prevented' & $\rightarrow$ & kinanna-m \\
tə-gy'enna-m & 'he crossed over' & $\rightarrow$ & tə-ginanna-m \\
b. ekkəsə-m & 'he waited' & $\rightarrow$ & ək'wak'š breyə-m \\
k'əččə-m & 'he feared' & $\rightarrow$ & ək'čač breyə-m \\
c. kəffətə-m & 'he opened' & $\rightarrow$ & kiraffətə-m \\
qəbbət'ə-m & 'he missed' & $\rightarrow$ & qirabbət'ə-m \\
d. noqqə-m & 'it barked' & $\rightarrow$ & nugnug 'dog' \\
nəc'c'ə & 'white' & $\rightarrow$ & nəc'əc'c'uwə \\
e. wəssəd-ə & 'he took' & $\rightarrow$ & waysdəd \\
t'ik'ur & 'black' & $\rightarrow$ & t'ayk'urər \\
\hline
\end{tabular}

It is likely that ludlings can lead to the creation of new roots and patterns when they become standard because the processes they employ are also attested in diachronic changes. This is clear with the addition of sonorants to Afroasiatic roots (Diakonoff 1988:42) and the creation of onomatopoeic and expressive patterns. The forms in (21) expressing noises in Lmnabha Moroccan Arabic, from Elmedlaoui 1995:57, illustrate how these two processes were involved in the transition from ludlings to dialectal forms. These patterns are now quite widespread throughout Morocco.

(21) Onomatopoeic forms in Lmnabha Moroccan Arabic

\begin{tabular}{|c|c|c|c|c|}
\hline \multirow{2}{*}{$\frac{\text { Onomatopoeia }}{\text { ttaq }}$} & \multirow{2}{*}{$\frac{\text { Reinforced form }}{\text { ttraq }}$} & \multirow{2}{*}{$\begin{array}{l}\text { Superreinforced form } \\
\text { trtllaqq }\end{array}$} & \multicolumn{2}{|c|}{ Derived verbs } \\
\hline & & & tqtiq & $\operatorname{trtiq}$ \\
\hline bbais & bbrais & brblla؟s & bibif & brbif \\
\hline bbaqq & bbraqq & brbllaqq & bqbiq & brbic \\
\hline ddagg & ddragg & drdllagg & dgdig & drdi \\
\hline ddaxx & ddraxx & drdllaxx & dxdix & $\operatorname{drdix}$ \\
\hline
\end{tabular}


The derived roots in the rightmost column behave like other quadriliteral roots in Moroccan Arabic, such as xrbiq 'he messed up'. For example, trtiq 'it exploded' can be used to form the inchoative (tt-trtiq vs. $t$-xrbiq), the active participle (m-trtiq vs. $m$-xrbiq), and action nouns ( $t$-trtiq vs. $t$-xrbiq).

\subsection{Template Misselection in Slips of the Tongue}

Template misselections are frequent in the speech of children (see Berman 1981:619 for Modern Hebrew examples). In adult speech, an Arabic slip of the tongue we observed recently is ?a-fdiy$a a$ ? 'self-sacrificing people', a nonexistent word formed from the root of fidaa?-iy 'self-sacrificing person' and the template of ?a-ṣdiq-aa? 'friends'. Abd-El-Jawad and Abu-Salim (1987:149) report several Arabic slips of the tongue that also fall into this category.

(22) Template misselection in Arabic slips of the tongue

\begin{tabular}{|c|c|c|c|}
\hline Target & & Error & Literal target gloss \\
\hline kalaam-ha șahiih & $\rightarrow$ & șahaah-ha kaliim & 'her talk correct' \\
\hline nabiil u kamaal & $\rightarrow$ & kamiil u nabaal & 'Nabeel and Kamal' \\
\hline hasan išqeer & $\rightarrow$ & šaqar iћseen & 'Hassan Shuqair' \\
\hline ma-țluub țaabiß-aat & $\rightarrow$ & ma-țbuuS țaalib-aat & 'wanted typists' \\
\hline il-watar il-hassaas & $\rightarrow$ & il-hasas il-wattaar & 'the favorite the subject' \\
\hline sakt-a qalb-iyy-a & $\rightarrow$ & qalb-a sakt-iyy-a & 'attack heart' \\
\hline bu-rquṣ Ya id-daqq-a & $\rightarrow$ & bi-duqq Sa ir-raqș-a & 'I dance to the beat' \\
\hline
\end{tabular}

In these errors, the two vocalized templates remain in situ while the two roots are switched. As a result, each root finds itself mapped to a template it should not select.

Similarly, the purpose of the following Amharic tongue twister is to entice speakers to err over the perfective template of (23a) and produce the nonword in (23b):

(23) a. al-an-nazzəz-accuh-accow-imm NEG-CAUS-confess-you-them-NEG 'you did not make them confess'

b. al-an-nəzaz-accuh-accəw-imm

The induced errors involve the change from $z z$ to $z$ in the stem (/nəzzəz/) and the reversal of the stem vowels (/a-ə/). Neither the resulting template (CVCVC) nor the resulting vowel sequence (/ə-a/) is legitimate in an Amharic verb in the perfective aspect.

To conclude this survey of external evidence for the basic components of Semitic words: we have shown that there is a parallel typology of circumstances in which metathesis errors and template misselections are observed: aphasic errors (section 2.1 vs. section 3.1), ludlings (section 2.2 vs. section 3.2), and slips of the tongue (section 2.3 vs. section 3.3). 


\section{Formal Properties of Aphasic Metathesis Errors}

We have argued that ZT's errors reveal an implicit knowledge of the root morpheme, but we must also provide more formal answers to the following two questions:

(24) a. Why does ZT produce more metatheses in Arabic than in French?

b. Why does ZT produce more bipartite than tripartite metatheses in Arabic?

We will attempt to answer these questions on the basis of ZT's errors because they provide the only empirical evidence to which we have full access. Berg and Abd-El-Jawad's (1996) study of Arabic and German slips of the tongue in unimpaired speakers cannot be used to address question (24a) because it is based on corpora of errors collected from "ambient conversations ... monitored for unintentional ouput" (p. 298), not from controlled stimulus sets such as those used in our study. As for question (24b), Berg and Abd-El-Jawad's study concurs with ours in reporting a greater proportion of bipartite than tripartite metatheses in Arabic, as will be discussed in section 4.2.

\subsection{Why Are Arabic Metatheses More Frequent?}

4.1.1 The Irrelevance of Phonotactic and Syllabic Constraints Let us first address question (24a). Recall from (5a-b) that ZT produced 5 consonant metatheses in French as opposed to 119 in Arabic. It seems necessary to tie the generalization in (24a) to the morphemic and floating nature of Arabic root consonants compared to the nonmorphemic and preanchored nature of French consonants. Neither phonotactic nor syllabic constraints can explain the differences between the errors in these two languages.

Consider phonotactic constraints first. Arabic has no (or few) phonotactic constraints on the nature of CC clusters (other than homorganicity constraints that restrict the content of the root). This means that consonant reversals in errors such as șfh- $a$ and $P a$-nrab-aat always result in the same C.C structure as that of the target forms-here, fuș-a and Pa-rnab-aat. French does have phonotactic constraints (see Dell 1995), but this difference does not explain why ZT makes so few metatheses on French clusters. Some French clusters would be reversible without changing the syllable structure (e.g., $k t, t l$, where the structure is C.C in both orders), whereas some other clusters would be reversible with a concomitant change in syllable structure (e.g., $r k, r t$, where the structure is C.C in one order and .CC in the other). It appears, then, that phonotactic constraints cannot account for why ZT made $28 \mathrm{CC}$ reversals in Arabic (e.g., qir $\rightarrow$ $\rightarrow$ qidr) but only one in French: ballerine [balrin] $\rightarrow$ [parlin]. What is more, even in Arabic, most of ZT's metatheses $(91 / 119=76.5 \%)$ do not involve clusters, which shows the limitations of any explanation based on phonotactic constraints.

Now, consider syllabic constraints. Recall from section 2.3 that Berg and Abd-El-Jawad's (1996) Germanic metatheses respect their Positional Constraint whereas their Jordanian Arabic ones do not. This is not the relevant difference in ZT's case because neither his French errors (e.g., ballerine [balrin] $\rightarrow$ [parlin]) nor his Arabic errors (e.g., miliaqa $\rightarrow$ miSlaqa) are sensitive to this constraint. Is it possible, then, that French branching onsets and codas make metatheses 
more difficult than do the nonbranching onsets and codas of Arabic? ${ }^{19}$ This would entail that French CVCVCV words such as pédalo 'pedal boat' would be propitious to reversals because no change in syllable structure would be involved. The lower rate of French errors would therefore stem from the fact that ZT's stimulus set did not contain enough words containing CV syllables only. To test this hypothesis, ZT was given a supplementary reading aloud task comprising 99 stimuli containing mostly CV syllables: $10 \mathrm{CVCV}, 46 \mathrm{CVCVCV}$, and $16 \mathrm{CVCVCVCV}$ word stimuli randomly mixed with 27 words containing other syllabic structures, such as CVC. The error rate in this test was very high: 71 errors out of 99 stimuli $=72 \%$ of errors. Among these 71 errors, 13 were semantic, 5 morphological, 9 visual, and 44 phonemic, but none included a consonant metathesis. Only one error, chicané [šikane] 'quarreled' $\rightarrow$ [šjẽka], may be construed as a metathesis error, but it would be one reversing vowels and consonants. Since even words composed of CV syllables fail to trigger metatheses, French syllable structure does not seem to be responsible for the lower rate of metatheses in this language. (See Béland and Paradis 1997 and Béland et al. 1999 for the effect of syllabic constraints in French-speaking aphasic patients.)

We maintain instead that the consonants of French are more stable than those of Arabic because they are preanchored. This entails that Arabic consonants are not preanchored, which means that they form roots. In both languages, the consonants are ordered, but the URs of Arabic roots need only contain precedence relations on one tier, as shown in (25).

\section{(25) UR of root ktb 'write'}

$\mathrm{k} \quad \mathrm{t} \quad \mathrm{b}$

In Indo-European languages, URs must contain precedence relations on both melodic and skeletal tiers (e.g., $\check{s}$ precedes $a$, which itself precedes $p$ in French [šapo] 'hat'), in addition to information about how the units on both tiers are connected to one another.

(26) UR of chapeau [šapo] 'hat'

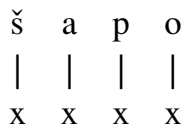

Whatever formalism is used to express precedence, the order of segments should be more stable in Indo-European than in Semitic because the links between the prosodic and segmental tiers are memorized, rather than derived by rules, principles, or constraints.

If ZT's errors originate from a deficit, common to both languages, in computing the precedence information, the higher frequency of consonant metatheses in Arabic must be imputed to differences between Arabic and French URs. Two characteristics distinguish these URs: (a) Arabic consonants float in UR, and (b) Arabic consonants and vowels occupy separate tiers because they belong to different morphemes. French segments cannot be said to float underlyingly for two reasons. First, some dialects of French have long consonants and long vowels whose positions must be learned for each word. Second, it is insufficient to preanchor long segments

\footnotetext{
${ }^{19} \mathrm{We}$ assume that the final CC clusters of Arabic do not form branching codas.
} 
only and leave short ones floating because there are many (short) latent consonants that can be distinguished from (short) permanent ones only if the former float (see Tranel 1995 and Paradis and El Fenne 1995 for recent overviews). The position of these floating consonants is unpredictable: some are word-final (e.g., petit [poti] 'small' vs. rite [rit] 'rite'), others are prefix-final (e.g., $/ \mathrm{de}^{\mathrm{s}}$-/ in désunir 'to disunite' vs. détendre 'to slacken'), and many floating nasals are word-internal (e.g., the one in bandit 'bandit', as Paradis and Prunet (2000) argue on the basis of borrowings). Preanchoring French segments therefore seems unavoidable. As there is no motivation for $\mathrm{C} / \mathrm{V}$ segregation in French, the URs of these languages differ in at least these two ways. It is reasonable to assume that the combination of both characteristics in Semitic is responsible for consonant metatheses' being so frequent in this family. Languages with only one of these two characteristics seem unlikely to display free consonant metatheses. Languages with no preanchoring and no C/V segregation, such as Basaa in Schmidt's (1994) analysis, would have no reason to metathesize consonants only since consonants are mixed with vowels on the segmental tier. Finally, we know of no analysis advocating the existence of the other combination, that is, preanchoring and $\mathrm{C} / \mathrm{V}$ segregation.

Within stem theories claiming URs to be the same in Semitic and non-Semitic languages, it could be argued that ZT's Arabic metatheses affect consonants only because Arabic has a constraint enforcing precedence relations between stem vowels. Whatever the empirical adequacy of such an analysis may be, we believe that it would contradict the basic premise of stem theories, which is that both Semitic and non-Semitic URs contain monomorphemic vocalized stems. Creating a constraint whose purpose is to allow reversals specific to the stem consonants of Arabic would amount to admitting that Arabic stem consonants are lexically different from their French counterparts. In our view, stem theories that likewise introduce processes of root extraction, transfer, or mapping that ignore Semitic vowels and affixal consonants all attempt to unify Semitic and non-Semitic word structure underlyingly but they reintroduce structural distinctions between Semitic and non-Semitic stem consonants later in the derivation. Our view is, rather, that UG allows morphemes to be specialized segmentally. They can be limited to vowels, consonants, and tones. Semitic simply exploits this option by having lexical morphemes containing (in most Semitic languages) only consonants.

4.1.2 Are ZT's Metathesis Errors Lexically Biased? The floating root rationale accounts for the frequency of ZT's errors in Arabic but not for the fact that so many of them are lexically biased. Recall from section 2.1.4 that there is presumption of lexical bias when the output coincides with an existing word or root. ZT produced 83 metatheses $(83 / 104=79.8 \%)$ in triliteral roots and 2 metatheses in quadriliteral roots $(2 / 12=16.7 \%)$ that may be lexically biased, that is, whose outputs coincide with existing words, as in (11), and/or roots, as in (12). We ignore the 3 errors on biliteral roots because these have only one reordering $(12 \rightarrow 21)$. By contrast, he produced no output coinciding with an existing word in French. This difference in lexical bias between his Arabic and French errors may, indeed, be due to the simple fact that Arabic exploits far more combinations of consonant orders than French does.

Consider the set of 71 triliteral roots over which ZT made metathesis errors. From an initial input 123 order, each root could yield five alternative orders: 132, 213, 231, 312, 321. A search in Kazimirski's (1860) dictionary for how many of these $5 \times 71(=355)$ alternative orders 
correspond to existing roots shows that random reversal has twice as many chances to coincide with existing than with nonexisting roots.

(27) Alternative orders for the 71 triliteral roots that ZT metathesized

\begin{tabular}{lrrrrr}
\hline Alternative order & 132 & 213 & 231 & 312 & 321 \\
Nonroot & 20 & 22 & 21 & 21 & 25 \\
Root & 51 & 49 & 50 & 50 & 46 \\
\hline
\end{tabular}

From this limited sample of roots, it appears that Arabic exploits most of the orders predicted by free combination of root consonants, that is, $69.3 \%$ ( 246 of the 355 combinations). ZT's output triliteral roots happen to coincide with existing roots $79.8 \%$ (i.e., 83/104) of the time, a proportion that is slightly but significantly higher at a .05 level $\left(\chi^{2}=3.87, p=.049\right)$. However, separate chi-squared analyses for the five reorderings were also conducted because the root subsets differ across the five reorderings and none of the five chi-squared values were significant at .05 level.

As for quadriliteral roots, a check in Kazimirski 1860 of how many of the 23 possible reorderings of the original 11 quadriliteral roots (i.e., $23 \times 11=253$ ) coincide with existing roots shows that only 32 of the possible combinations $(32 / 253=12.6 \%)$ coincide with existing roots. This is because quadriliteral roots are subject to known segmental constraints (such as the near obligatoriness of having a sonorant as second consonant). As reported earlier, the proportion of ZT's output quadriliteral roots coinciding with existing roots is $2 / 12=16.7 \%$, a proportion that does not significantly differ from the one found in the dictionary $\left(\chi^{2}=.001, p>.05\right)$.

From these statistical analyses, we conclude that it is only by chance that ZT produced reorderings of triliteral and quadriliteral root consonants that coincide with existing roots.

4.1.3 Further Evidence for the Floating Root Consonants of Semitic Let us return to our claim that the order of stem consonants is easier to disrupt in Arabic than in French. There are two other aspects of Arabic that can be mentioned in this context.

First, the ease of root consonant reversal in aphasia, ludlings, and slips of the tongue can be related to the fact that Arabic has a number of synonymous roots containing the same consonants in different orders. The examples in (28) are drawn from Bohas 1997, to which the page numbers refer. Expressions such as verbal pattern 4 indicate that this root selects the 4th of the 15 verbal patterns of Arabic.

(28) Synonymous Arabic roots containing the same consonants in different orders

\begin{tabular}{lllllll}
\hline Page & Root & Word & Gloss & Root & Word & Gloss \\
\hline 7 & brt & $\begin{array}{l}\text { bart } \\
\text { burt }\end{array}$ & $\begin{array}{l}\text { 'action of cutting' } \\
\text { 'axe' }\end{array}$ & btr & batar-a & $\begin{array}{l}\text { 'to cut, to cut off } \\
\text { the tail of an } \\
\text { animal' }\end{array}$ \\
7 & bšr & Pa-bšar-a & $\begin{array}{l}\text { 'to grow herbs and } \\
\text { plants' }\end{array}$ & rbš & rabiš-un & $\begin{array}{l}\text { 'having herbs of all } \\
\text { kinds' }\end{array}$ \\
& & & Pa-rbaš-u & $\begin{array}{c}\text { 'covered with } \\
\text { plants (of land)' }\end{array}$
\end{tabular}




\begin{tabular}{|c|c|c|c|c|c|c|}
\hline 98 & bwx & $\begin{array}{l}\text { baax-a } \\
\text { /bawax/ }\end{array}$ & $\begin{array}{l}\text { 'to calm oneself, to } \\
\text { go out (of fire, } \\
\text { heat, anger)' }\end{array}$ & bxw & $\begin{array}{l}\text { baxa-a } \\
\text { /baxaw/ }\end{array}$ & $\begin{array}{l}\text { 'to calm oneself, to } \\
\text { subside (of } \\
\text { anger)' }\end{array}$ \\
\hline 112 & hwq & $\begin{array}{l}\text { haaq-a } \\
\text { /hawaq/ }\end{array}$ & $\begin{array}{l}\text { 'to sweep (with a } \\
\text { broom)' }\end{array}$ & qwh & $\begin{array}{l}\text { qaah-a } \\
\text { /qawah/ }\end{array}$ & $\begin{array}{l}\text { 'to sweep (with a } \\
\text { broom)' }\end{array}$ \\
\hline 113 & ћkw & $\begin{array}{l}\text { haka-a } \\
\text { /hakaw/ }\end{array}$ & $\begin{array}{l}\text { verbal pattern } 4: \text { 'to } \\
\text { win, to get the } \\
\text { better of someone' }\end{array}$ & kwh & $\begin{array}{l}\text { kaah-a } \\
\text { /kawah/ }\end{array}$ & $\begin{array}{l}\text { verbal pattern 3: 'to } \\
\text { beat someone, to } \\
\text { have the upper } \\
\text { hand' }\end{array}$ \\
\hline 123 & $\mathrm{rf}$ & rafraf-a & $\begin{array}{l}\text { 'to spread and shake } \\
\text { wings (of a bird)' }\end{array}$ & fr & farfar-a & $\begin{array}{l}\text { 'to shake, to shake } \\
\text { one's body (of } \\
\text { an animal)' }\end{array}$ \\
\hline 126 & $\mathrm{zl}$ & zalzal-a & 'to shake' & lz & lazlaz-a & 'to be shaken' \\
\hline 130 & sn & $\begin{array}{l}\text { sann-a } \\
\text { /sanan/ }\end{array}$ & $\begin{array}{l}\text { 'to lead in front of } \\
\text { oneself' }\end{array}$ & ns & $\begin{array}{l}\text { nass-a } \\
\text { /nasas/ }\end{array}$ & $\begin{array}{l}\text { 'to lead in front of } \\
\text { oneself' }\end{array}$ \\
\hline 134 & twi & $\begin{array}{l}\text { țaaS-a } \\
\text { /țawaS/ }\end{array}$ & $\begin{array}{l}\text { 'to obey someone, to } \\
\text { be at someone's } \\
\text { disposal' }\end{array}$ & Sṭw & $\begin{array}{l}\text { Saṭa-a } \\
\text { / Sațaw/ }\end{array}$ & $\begin{array}{l}\text { verbal pattern 2: 'to } \\
\text { serve someone'; } \\
\text { verbal pattern 4: } \\
\text { 'to be obedient, } \\
\text { to allow oneself } \\
\text { to be led' }\end{array}$ \\
\hline 136 & Swq & Suwaaq & $\begin{array}{l}\text { 'noise produced in an } \\
\text { animal's belly } \\
\text { while walking' }\end{array}$ & wiq & wuSaaq & $\begin{array}{c}\text { 'noise produced in } \\
\text { a horse's belly } \\
\text { while walking' }\end{array}$ \\
\hline 137 & yfn & yafan & $\begin{array}{l}\text { 'disease of dates } \\
\text { which consists of } \\
\text { dust that covers } \\
\text { them and prevents } \\
\text { them from } \\
\text { ripening' }\end{array}$ & fyn & fayan & $\begin{array}{l}\text { 'disease of dates } \\
\text { which consists of } \\
\text { dust that covers } \\
\text { them and } \\
\text { prevents them } \\
\text { from ripening' }\end{array}$ \\
\hline
\end{tabular}

The pair of Wello Amharic roots $k^{\prime} t^{\prime} l$ and $l t^{\prime} k^{\prime}$ is comparable to these Arabic pairs. Both roots mean 'following' in $k^{\prime} \partial t^{\prime} t t^{\prime} i l-o$ and $l a t^{\prime} t$ ' $i k^{\prime}$ - $o$ but they are distinct lexical entries since, among other reasons, $k^{\prime} \partial t^{\prime} t$ ' $\partial l-\partial$ 'he continued, he fastened' is not paralleled by *lat't' $\partial k^{\prime}-\partial$. Bohas (1997:64) notes that the existence of such pairs of roots in Semitic was identified at least as early as Cohen 1955:207, where it is stated that "apparently triliteral roots seem to lend themselves easily to metathesis.',

Similar examples of root consonant reversals can be found in dialects of modern Arabic. In some cases, the metathesis is observable diachronically (29) whereas in others, the resulting doublets coexist in contemporary dialects or sociolects (30). On our assumption that frequent metathesis affects root consonants, the non-Semitic origin of the last four Egyptian Arabic words in (30) must be interpreted as evidence for a process of root extraction operating also on loanwords. Such a process is independently needed in the nativization of borrowings, as in the Moroccan 
Arabic verb diwwiš 'he showered', formed from the French noun douche [duš] 'shower'. It is also needed in first language acquisition since children are exposed to words, not abstract roots, though in our view they deconstruct and store these words as roots and templates after becoming aware of paradigmatic regularities.

(29) Diachronic root consonant reversals in Maghrebi Arabic

\begin{tabular}{|c|c|c|c|}
\hline Classical Arabic & Moroccan Arabic & Tangier Moroccan Arabic & Gloss \\
\hline dažaaž & džaž & ždad & 'poultry' \\
\hline lain-a & ni९l-a & & 'cursing' \\
\hline zaim-an & zịma & zimia & 'presumably' \\
\hline rayaayif & $\begin{array}{l}\text { ryayif } \\
\text { tikki }\end{array}$ & $\begin{array}{l}\text { Tahir Algerian Arabic } \\
\text { yrayif } \\
\text { kitti }\end{array}$ & $\begin{array}{l}\text { 'sort of bread' } \\
\text { 'to lean' }\end{array}$ \\
\hline
\end{tabular}

(30) Contemporary root consonant reversals in Egyptian Arabic

\begin{tabular}{lll}
\hline Standard Egyptian Arabic & Colloquial Egyptian Arabic & Gloss \\
\hline Pa-raanib & Pa-naarib & 'rabbits' \\
ma-srah & ma-rsah & 'theater' \\
hafar & fahar & 'he dug' \\
ka?iib & Pikib & 'sad' \\
haffaar-a & faћhaar-a & 'mechanical shovel' \\
litr & ritl & 'liter' \\
falsaf-a & falfas-a & 'philosophy' \\
barțamaan & bațramaan & 'glass/plastic jar or tin' \\
skindiriy-a & stinkiriy-a & 'Alexandria' $(d \rightarrow t$ after $s)$ \\
\hline
\end{tabular}

Zaborski (1991:1687-1688) provides more such examples from Arabic and other Semitic languages. Leslau (1992:97-98) also discusses similar metatheses in Gurage dialects, reproduced in (31). Some pairs cooccur in the same dialect whereas others belong to different dialects. As with the Egyptian Arabic words, metathesis is not limited to words of Semitic origin, which is again evidence for a root extraction process applying to all words in acquisition and nativization. The examples in (31a) are Semitic words, those in (31b) come mostly from Cushitic, and those in (31c) are of unclear origin. The number in the rightmost column refers to the page in Leslau's (1979) etymological dictionary where the origin of the word is discussed.

(31) Root consonant reversals in Gurage dialects

\begin{tabular}{llll}
\hline Dialectal form & Dialectal form & Gloss & Page \\
\hline a. ibliis (<Arabic) & ilbis & 'evil spirit' & 8 \\
gəzzərə, gərrəzə (<Amharic) & gərəzə & 'to circumcise' & 297 \\
kəbəro & kərəbo & 'drum' & 334
\end{tabular}




\begin{tabular}{|c|c|c|c|}
\hline killkil & liklikk & 'armpit' & 340 \\
\hline kəzəbə (<Arabic) & kəbəzə & 'to lie' & 359 \\
\hline kizb $(<$ Arabic $)$ & kibz & 'people' & 359 \\
\hline saß?at & sa?abt & ‘seven' & 534 \\
\hline silət't'ənə (<Arabic) & sinət'ələ & 'to have an education' & 545 \\
\hline t’əbt'ət & t'ət'bət & 'early morning' & 608 \\
\hline t'iwwalləgə & t’oggələ & 'to wither' & 637 \\
\hline b. borkətta & botrəka & 'crack in the ground' & 163 \\
\hline fišara & fïrša & 'sediment of water' & 247 \\
\hline $\mathrm{g}^{\mathrm{w}}$ ədrət & $\mathrm{g}^{\mathrm{w}}$ ərdət & 'mound around fireplace' & 265 \\
\hline k'aššawe? & k'awše & 'type of game' & 506 \\
\hline arwa $(<$ Arabic arwaah?) & awro & 'soul' & 93 \\
\hline c. birč'วk'k'o & bič'rik'k'o & 'drinking glass' & 152 \\
\hline bəttir & bərt & 'stick' & 163 \\
\hline gələmə & $\mathrm{g}^{\mathrm{y}}$ əmmələ & 'to sew leather' & 309 \\
\hline igzər & izgir & 'God' & 28 \\
\hline kəsəl & səhəl & 'charcoal' & 353 \\
\hline indəxrečə & indərheččə & 'kidney’' & 59 \\
\hline t’ulbuk' & t'ubuluk' & 'to plunge into water' & 617 \\
\hline at'met & amĩ?ĩd & 'solidified juice' $(t$ ' $\rightarrow$ ? $)$ & 109 \\
\hline wəfənča & wənəfč-ar & 'doorway' & 645 \\
\hline awsač & aswaččat & 'trap' & 667 \\
\hline wizgibbər & wizbiggər & 'repentance' & 675 \\
\hline azgalid & azlagid & 'cloth belt' & 120 \\
\hline
\end{tabular}

More diachronic examples of bipartite and tripartite reversals exist in Classical Ethiopic (Dillmann 1907:108) and Amharic (Cohen 1970:56).

We have surveyed five phenomena where Arabic and other Semitic languages distinguish themselves by the ease with which their consonants can be reordered, synchronically (32a-c) or diachronically (32d-e).

(32) a. Unusually high number of consonant reversals in aphasic speech

b. Only known ludlings exhibiting random consonant reversals

c. Unusually high number of consonant reversals in slips of the tongue

d. Synonymous roots sharing the same consonants in different orders

e. Diachronic consonant reversals

We have suggested that this ease of reversal is due to (a) the existence of roots, and (b) the fact that roots include floating consonants. Some metatheses are also found outside of Semitic, as in the aphasic errors and slips of the tongue noted in French (section 2.1.2) and Germanic (section 2.3), but much less frequently so. They are also (rarely) seen in historical data, as in the 100 cognate sets of Salish roots identified by Noonan (1997) whose consonants are ordered 
differently in related languages, as in Shuswap $x^{w} e y$ 'disappear' and Twana $y \partial x^{w}$ 'disappear' (p. 482). These data are reminiscent of the historical Semitic metatheses illustrated in (29)-(31), but they can be explained in two other ways. First, Noonan raises the possibility that they may come from ancient ludlings, in which case they are not comparable to Arabic ludlings, since exchanging the first and last consonants of a CVC root does not qualify as random reversal. Second, these metatheses could be due to the predictability of segmental order since CVC is the most common root pattern in Salish. This would make the CVC pattern of Salish comparable to the default pattern of a Semitic language displaying a very small inventory of patterns. It is possible that the frequency of CVC roots in a small set of root structures prompts Salish speakers to store their consonants as floating underlyingly. In addition, there is evidence of some templatic morphology, as in the aspectual distinction in Klallam between / xíc'-/ 'scratch (ACTUAL ASPECT)' and /xc'í-/ 'scratch (NONACTUAL ASPECT)' (Czaykowska-Higgins and Kinkade 1998:22, 24). McCarthy (1989) suggests that consonants and vowels can stand on different tiers in languages that have rigid word structure or templatic morphology because the canonical shape of words contains enough information to dispense URs from storing the respective order of consonants and vowels. Since Salish seems to meet both conditions, it is possible that Salish roots include floating consonants and vowels on different tiers if their respective order can be derived from association conventions. Once consonants and vowels stand on separate tiers, we suggest, there is no motivation for them to be preanchored.

\subsection{Bipartite and Tripartite Metatheses}

Now consider question (24b). If root consonants can be reversed easily because they float in Arabic URs, why did ZT produce as many as 91 bipartite but as few as 13 tripartite errors in Arabic?

As mentioned in section 2.2, there are five possible permutations of three consonants. Three of them are bipartite $(123 \rightarrow 132,213,321)$ and two are tripartite $(123 \rightarrow 312,231)$. If permutations were random, one would expect $3 / 5=60 \%$ bipartite reversals and $2 / 5=40 \%$ tripartite reversals, a distribution that differs from the one observed $(91 / 104=87.5 \%$ bipartite and $13 / 104=12.5 \%$ tripartite). The difference is significant $\left(\chi^{2}=19.37, p<.0001\right)$.

This disproportion is also present in Berg and Abd-El-Jawad's (1996) corpus of Jordanian Arabic slips of the tongue, which contains 316 bipartite and 24 tripartite metatheses, that is, $92.95 \%$ and $7.05 \%$, respectively. It is, in fact, a surprising finding that the proportion of bipartite and tripartite metathesis errors is not statistically different in their Arabic corpus and ours $\left(\chi^{2}=\right.$ $2.42, p>.05)$.

One possibility that would account for the higher proportion of bipartite metatheses would be a lexical bias, that is, a tendency for ZT to produce existing roots. This possibility is ruled out for two reasons. First, as established in section 4.1.2, ZT does not show a lexical bias; that is, he does not err in favor of existing roots more than chance predicts. Second, even if he did show such a bias, the distribution of existing and nonexisting roots in (27) is uniform across the five reorderings ( $\left.\chi^{2}=0.98, p>.05\right)$. As a consequence, a tendency to produce an existing root would not account for a higher proportion of bipartite (reorderings 132, 213, 321) over tripartite 
metatheses (reorderings 312, 231) since whatever the reordering chosen by ZT, the output root is twice as likely to coincide with an existing root as it is with a nonexisting one.

With a 1 to 9 imbalance, tripartite metatheses are much rarer than bipartite ones in Arabic, but the disproportion is even greater in Indo-European. As far as slips of the tongue are concerned, Berg and Abd-El-Jawad (1996) report 24 tripartite errors in Arabic and none in German even though their Arabic corpus is six times smaller than their German corpus $(N>1000$ and $N$ $>6000$, respectively). In the Indo-European aphasic literature, tripartite metatheses are almost unknown. The largest corpus of metatheses is that of Blumstein (1973) for English. She states that among the 123 intramorphemic metathesis errors she collected, contiguous ones (e.g., magazine [mægəzin] $\rightarrow$ [mæzəgin]) were far more frequent than noncontiguous ones (e.g., pastry [peistri] $\rightarrow$ [preisti]). ${ }^{20}$ Dressler (1990) reports one tripartite metathesis by an Italian-speaking aphasic: sigaretta 'cigarette' [sigaretra] $\rightarrow$ [risagetra]. Metathesis errors were also reported in studies of French-speaking aphasics. Lecours and Lhermitte (1969) mentioned 15 metathesis errors by two jargon aphasic patients: 5 of them involved a consonant and a vowel (e.g., silhouette 'silhouette' [siluct] $\rightarrow$ [siulet]), 3 involved the reversal of two elements of digraphs (e.g., froid 'cold' [frwa] $\rightarrow$ friod), 6 were bipartite consonant metatheses (e.g., cravate 'tie' [kravat] $\rightarrow$ [travak]), and only

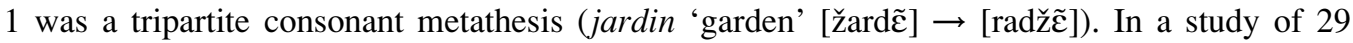
French-speaking aphasics, Béland (1998) reported 20 metatheses: 13 of them involved the reversal of a vowel and a consonant (e.g., forêt [fore] 'forest' $\rightarrow$ [foer]) and 7 the reversal of two consonants (e.g., gifle [žifl] 'slap' $\rightarrow$ [žilf]). Finally, all 3 reversals reported by Valdois and Nespoulous (1994) are also bipartite (moutarde 'mustard' [mutard] $\rightarrow$ [murtad], carton 'cardboard' [kart̃̃] $\rightarrow$ [krat], and cafetière 'coffee-maker' [kafœtjer] $\rightarrow$ [fakœtjer]). In summary, the Italian example [sigaretra] $\rightarrow$ [risagetra] and the French example [žard $\tilde{\varepsilon}] \rightarrow[\operatorname{radž} \tilde{\varepsilon}]$ are the only two cases of tripartite metathesis known to us in the aphasic literature. If, as we have argued, bipartite metatheses are rare in Indo-European because they destroy the ordering information expressed by the underlying preanchoring of segments, it is correctly predicted that tripartite ones will be even rarer in this language family since they are even more destructive of the UR structure.

It appears, then, that metatheses, both in aphasic speech and in slips of the tongue produced by unimpaired speakers, are governed by a principle of minimal disruption. Metatheses are produced but those that disrupt less of the original order are favored. In the case of Arabic, the tendency toward minimal disruption can be captured by stating that it is preferable to displace two consonants rather than three, or that minimal crossing is favored over maximal crossing during the mapping of root consonants to the template. Outside of Semitic, the same formal alternatives are available: minimal movement or minimal line crossing, with the added property

\footnotetext{
${ }^{20}$ Blumstein does not include her corpus, so we cannot reanalyze it according to the notions of bipartite versus tripartite and contiguous versus noncontiguous. She categorizes errors according to a measure of distance 1 (the consonant changes position either with the consonant nearest to it or with the vowel directly contiguous to it; e.g., magazine $\rightarrow$ mazagine, colts $\rightarrow$ clots), distance 2 (the consonant is moved around another consonant, with no reversal; e.g., professor $\rightarrow$ pofressor), and distance 3 (the consonant moves around two or more consonants; e.g., pastry $\rightarrow$ prasty). For the purpose of comparison, we approximate her terms and ours as follows: errors she classifies as distances 1-2 are treated here as contiguous; errors she classifies as distance 3 are treated here as noncontiguous.
} 
that consonants are preanchored and interspersed with vowels. As a consequence, any movement of consonants or crossing of consonant-to-skeleton links is more disruptive than it is in Semitic and, hence, is correctly predicted to be less frequent.

Distinguishing between bipartite and tripartite metatheses is, in our view, useful because it predicts a frequency-based division of errors that matches ZT's errors. Equating minimal and maximal disruption with bipartite and tripartite, respectively, predicts a two-way frequency gradation that is confirmed by our empirical findings.

(33) Distribution of ZT's metatheses as bipartite and tripartite in triliteral roots

\begin{tabular}{ll}
\hline Bipartite $(n=91)$ & Tripartite $(n=13)$ \\
\hline $123 \rightarrow 321=15$ & $123 \rightarrow 231=5$ \\
$123 \rightarrow 132=36$ & $123 \rightarrow 312=8$ \\
$123 \rightarrow 213=40$ & \\
\hline
\end{tabular}

Within the class of bipartite metatheses, two subclasses can be distinguished according to whether they displace consonants that are contiguous $(123 \rightarrow 132,123 \rightarrow 213)$ or noncontiguous $(123 \rightarrow 321,123 \rightarrow 231,123 \rightarrow 312)$. Random permutations predict $2 / 5=40 \%$ contiguous and $3 / 5=60 \%$ noncontiguous metatheses. ZT actually produced $76 / 104=73 \%$ contiguous and $28 /$ $104=27 \%$ noncontiguous metatheses. This distribution differs significantly from the one expected $\left(\chi^{2}=21.32, p<.0001\right)$. The fact that contiguous metatheses are more numerous than expected is consistent with the logic of minimal disruption laid out earlier.

Several means of encoding minimal and maximal disruption are possible, but they do not seem to shed as useful a light on the data as does the division between bipartite and tripartite metatheses.

An anonymous reviewer suggests a classification based on the number of modifications made to the original linear order of consonants in the target 123 root; that is, 1 is before 2, 2 is before 3 , and 1 is before 3 . This approach predicts a three-way frequency distribution of metatheses, from the smallest to the largest number of violations of the underlying linear order. The most minimal disruption is predicted to be of type $1(123 \rightarrow 213$ and $123 \rightarrow 132)$ because only one order is modified in the target. For instance, in 213, 1 is no longer before 2 but 1 remains before 3 and 2 before 3 . A greater disruption would be that of type $2(123 \rightarrow 312$ and $123 \rightarrow 231)$. In these two reorderings, two of the original linear orders are modified. For instance, in 231, 2 is no longer after 1 and 3 is no longer after 1. Finally, the greatest amount of disruption is predicted to be that of type $3(123 \rightarrow 321)$. In this reordering, all three original orders are changed: 1 is no longer before 2,1 is no longer before 3 , and 2 is no longer before 3 . The predicted frequency gradation is therefore type $1>$ type $2>$ type 3 , from the smallest to the largest number of violations of the underlying consonant order.

Classifying ZT's 104 errors on triliteral roots according to this typology yields the following distribution: type $1=76$, type $2=13$, type $3=15$. Type 3 metatheses are predicted to be the least frequent, but they are actually more frequent than type 2 metatheses. It thus appears that 
the classification into bipartite and tripartite metatheses in (33) makes better predictions for the distribution of metatheses produced by ZT.

Applying the reviewer's suggestion to ZT's quadriliteral root errors predicts a four-way gradation: from one to four violations of the underlying linear ordering. This typology predicts the following empirical distribution of ZT's 12 errors: type $1=8$, type $2=1$, type $3=3$, type $4=0$. As expected, the highest frequency in the distribution corresponds to type 1; but it is also the only type of metathesis that is bipartite. As a consequence, our analysis equating minimal disruption with the smallest number of displaced consonants (or crossed association lines) makes the same prediction.

In this section, we have proposed that root consonants are floating and morphemic in Arabic but preanchored and nonmorphemic in French. This explains the quantitative difference in metathesis errors between the two languages. ZT's performance in French and Arabic being identical in all respects except for consonant metathesis, we conclude that the consonantal root is a morpheme in Arabic, on a par with affixes and the template. The external evidence documented here suggests that the lexical units of Semitic correspond exactly to the size of the traditional consonantal root. Some authors argue, instead, for lexical units that are larger or smaller than the root. Some claim that the vocalized word or stem is the basic unit of word formation (see, e.g., Mahadin 1982, Heath 1987, Bat-El 1994, Ratcliffe 1997, and Ussishkin 1999). In these models, the URs of Semitic words match those of Indo-European languages since both include preanchored consonants and vowels on the same segmental plane. The problem with this approach is twofold: (a) it does not seem to account for the evidence showing that several processes are sensitive to Semitic root consonants, and (b) it does not seem to explain why so many processes are sensitive to the vocalized stem in Indo-European but not in Semitic. A frequent argument put forth by stem theorists consists in showing the existence of rules transforming a stem into another stem without recourse to the root unit. However, we suggest that such rules do not argue against roots as much as they argue for the necessity of output-to-output rules. We do not exclude these rules as long as the stored lexical units contain roots on a distinct morphemic tier. Other authors, after Bohas (1997), claim that all triliteral roots are composed of two synchronic units: (a) a biradical lexeme Bohas calls the etymon, and (b) a meaningless sonorant extension. Yet our evidence points to no such division in metathesis errors: the only synchronic distinction identifiable in our aphasic data, ludlings, and slips of the tongue is, as far as can be determined, that between root consonants and affixes. This is unexpected for etymon theory since it recognizes etymons and stems, but not roots, as legitimate morphological constituents. However, doing justice to these alternative views would require systematic formal comparisons between etymon-, root-, and stem-based theories, a task beyond the scope of this article. These comparisons will have to account for the evidence presented in the aforementioned studies, as well as for that introduced here.

\section{Conclusion}

In this article, we have argued that the consonant metathesis errors produced by ZT, a bilingual Arabic-French aphasic patient, provide external evidence for the existence of roots as lexical units 
in the mental lexicon of speakers of Arabic. These errors differ quantitatively (error rate) and qualitatively (error types) in his two languages. We have suggested that these differences are compatible only with models in which the URs of Semitic languages are fundamentally different from those of non-Semitic languages. Because ZT has parallel linguistic deficits in his two languages, his metatheses must arise during the phonological planning stage in both languages. The same deficit yields different effects because the phonological representations of these languages are different: the radical consonants of Arabic float on the root tier in URs whereas those of French are preanchored and interspersed with vowels. The existence of roots as lexical units implies the existence of morphemes as lexical units and therefore favors morpheme-based models of morphology, or at least models that can store morphemes on distinct tiers. Our evidence does not exclude the existence of output-to-output rules.

We have also shown that postulating different morphological representations for Semitic and non-Semitic words predicts a typology of aphasic deficits that is confirmed by the existing literature, at least as far as the root and template/vowel division is concerned. This typology was justified independently by showing that there exists a parallel typology of ludlings and slips of the tongue for Semitic and non-Semitic languages. This typology is based on phonological operations in Semitic, such as reversals of root consonants, and morphological operations, such as template misselections.

Finally, we have formalized the way in which consonant metatheses take place more easily in Semitic than elsewhere. This accounts not only for qualitative differences between Arabic and French but also for quantitative differences between and within these languages. Five types of evidence for the ease with which consonants can be reordered in Semitic were put forward, most of which set Semitic URs apart from those of other language families.

\section{Appendix}

The following is an exhaustive list of ZT's 119 Arabic metathesis errors sorted in alphabetical order by root. Outputs produced in the writing-to-dictation task are followed by *.

\begin{tabular}{|c|c|c|c|c|c|}
\hline Target root & Target & Output & Target root & Target & Output \\
\hline アðn & ma-?aaðin & ma-daa?in & $\mathrm{b}(\mathrm{w}) \mathrm{xr}$ & baaxir-a & baarix-a \\
\hline ?nf & Pis-t-a?naf-naa & ?is-t-afne? & $\mathrm{b}(\mathrm{w}) \mathrm{xr}$ & bawaaxir & baraaxiw \\
\hline ?nf & Pis-t-i?naaf & Pis-t-ifnaa? & $\mathrm{b}(\mathrm{w}) \mathrm{xr}$ & bawaaxir & baxaarib \\
\hline Sbd & ma-Ybad & ma- $\{d a b$ & $\mathrm{b}(\mathrm{w}) \mathrm{xr}$ & bawaaxir & baxaawir \\
\hline Sdn & ma-Yaadin & ma-daafin & $\mathrm{bS} \theta \mathrm{r}$ & baitar & baịra $\theta$ \\
\hline @mr & mu-s-t-aimir & mu-s-t-am irir & bḍ & biị̣ & diib \\
\hline Sqrb & Saqaarib & Sanaaqib & $\dot{\text { brq }}$ & Pi-briiiq & Pंi-qbiir \\
\hline Srž & Saṛž-aa? & Sažr-aa? & byḍ & baayiḍ & baaḍiy \\
\hline @šb & Gušb & šuSb & byḍ & buyḍ & buḍy \\
\hline Sṭf & Pis-t-aițaf & Pis-t-âfat & byḍ & buyd & yadiab \\
\hline Sṭf & Pis-t-âțaf-naa & Pis-t-aftai $\dot{i}$-naa & $\mathrm{bhr}$ & bahr & $\hbar b r *$ \\
\hline ițf & Pis-t-iYțaaf & Pis-t-ifțaas & drž & Pis-t-adraž & Pis-t-ažrad \\
\hline Sṭf & mi-Sțaf & mi-ţaf & drž & darraaž-a & dažraaž-a \\
\hline Sṭf & mu-s-t-åțif & mu-s-t-aSfit & $\mathrm{dxl}$ & daxal & xadal \\
\hline
\end{tabular}




\begin{tabular}{|c|c|c|c|c|c|}
\hline Target root & Target & Output & Target root & Target & Output \\
\hline $\mathrm{dxl}$ & ma-dxal & xadal & rwh & Pis-t-iraah-a & Pis-t-ihaar-a \\
\hline Øِrf & ?a-ọrif-a & ใa-ọfir-a & šyṭn & šayaațiin & šaṭaayiin \\
\hline$\partial \partial_{\mathrm{rrf}}$ & Pa-ð̣̆rif-a & Pa-fọir-a & $\mathrm{sbh}$ & ma-sbah & ma- $\hbar b a s$ \\
\hline ợrf & ọarf & Ø̣afr & sqf & Pu-squf & Pu-fqus \\
\hline fir & fa?r & far? & sqf & Pu-squf & Pu-fqus \\
\hline fhd & fahd & hdf* & & & (repeated error) \\
\hline fnžn & fanaažiin & fažaaniin & sqf & Pu-squf & Pu-qsuf \\
\hline fqr & fuqar-aa? & furaq-aa? & sqf & saqf & faqs \\
\hline frs & faras & fasar & stð & ?a-saatið-a & ?a-saadis-a \\
\hline frs & ma-fras-a & ma-rfas-a & sxy & saxaa? & xasa \\
\hline frš & faraaš-aat & fašaar-aat & sžd & ma-sžid & ma-ždis \\
\hline fšl & faašil & šaafil & ș̣ & șafh & șhb* \\
\hline fšl & fašil & šafil & șfh & șafh-a & șhf-t* \\
\hline fṣh & fușh-aa & șufh-a & șmr & mi-șmaar & m-mṣaar* \\
\hline fḥs & fahas & fașah & șhf & mu-șhaf & m-ṣfï* \\
\hline fhṣ & fuhuus & fuṣuuh & șff & șahaa?if & șafaa?ih \\
\hline fhṣ & ta-fahhas & t-ṣfr* & șhf & șahaaf-a & șfaah-t* \\
\hline fhṣ & ta-fahћuṣ & ta-haffuṣ & tby & tiby & tiyib \\
\hline hdf & Pis-t-ihdaaf & Pis-t-ifdaah & tlfn & tilifuun & tfluun* \\
\hline hms & hams & mhas & $\theta y b y$ & PiӨyuubyaa & Pabyuu $\theta$ yаa \\
\hline hrž & ma-hraž-aan & ma-ṛhaž-aan & tžr & ma-tžar & ma-žtar \\
\hline $\mathrm{k}$ ?s & kuPuus & kusuu? & trbš & țarbuuš & tašbuur \\
\hline ktb & ta-kaatub & ka-ta-atub & țq & mi-ṭraq-a & mi-qțar-a \\
\hline $19 q$ & ma-laaSiq & ma-Saaliq & yrq & ya-yraq-uun & na-rqai-uun \\
\hline $1 \mathrm{iq}$ & mi-19aq-a & mi-\{laq-a & wqf & Pa-wqaaf & ?a-wfaaq \\
\hline $19 q$ & mi-19aq-a & $\begin{array}{l}\text { mi-Slaq-a } \\
\text { (repeated error) }\end{array}$ & $\begin{array}{l}\text { wqf } \\
\text { ws }\end{array}$ & $\begin{array}{l}\text { ta-waqquf } \\
\text { waasii-a }\end{array}$ & $\begin{array}{l}\text { ta-qawwuf } \\
\text { waSiiis }\end{array}$ \\
\hline lwh & lawh-a & walh-a & wžs & wažas & žawas \\
\hline lymn & laymuun & malyuun & xnzr & xanaaziir & xazaaniir \\
\hline $1 \mathrm{hm}$ & ma-lham-a & ma-hlam-a & $\mathrm{xrž}$ & mu-xriž & mu-xžir \\
\hline $1 \mathrm{hm}$ & ta-laahum & ta-laamuh & žfn & Pa-žfaan & ?a-šbaan \\
\hline ms? & masaa? & smaa?* & žhd & ma-žhuud & ma-žduuh \\
\hline msh & masah & samah & žl & ma-žall-a & $m-l z ̌-t *$ \\
\hline$n b t$ & nabat & bint & žls & ma-žlis & m-lžs* \\
\hline ndy & nidaa? & dinaa? & žnh & žinh & žiћn \\
\hline nṣb & ma-nșuub & ma-ṣnuub & $\mathrm{zhr}$ & Pa-zhaar & Pa-zraah \\
\hline nṭq & mi-nțaq-a & m-ṭnq-t* & $\mathrm{zhr}$ & zahr & hzr* \\
\hline nṭq & nuṭq & nuqt & $\mathrm{zl}$ & ta-zalzal & ta-lazlaz \\
\hline nxl & naxl & xanl & $\mathrm{zr}$ & zaṛ̂-aat & zazr-aat \\
\hline nzl & ma-naazil & ma-laazin & $\mathrm{zr}$ & zirr & rịẓ̇ \\
\hline qbtn & qubtaan & quṭaan & $\mathrm{zrf}$ & zaraaf-a & zafaar-a \\
\hline qrd & qird & qidr & $\mathrm{zrf}$ & zaraaf-a & zfraa-t* \\
\hline qrd & quruud & quduur & ћbl & hubul & hulub \\
\hline qws & qaws & swt* & hml & Pih-t-imaal & Pih-t-ilaam \\
\hline ris & ru?as-aa? & rusa?-aa? & hmq & hamq-aa? & haqm-a \\
\hline rkz & ma-rekaz & $\mathrm{m}-\mathrm{krz} *$ & hṣd & hașṣaad & șahћaad \\
\hline $\mathrm{rnb}$ & Pa-rnab-aat & ?a-nrab-aat & & & \\
\hline
\end{tabular}




\section{References}

Abd-El-Jawad, Hassan, and Issam Abu-Salim. 1987. Slips of the tongue in Arabic and their theoretical implications. Language Sciences 9:145-171.

al-Makhzuumii, Mahdi, and 'Ibraahiim as-Saamarraa'ii, eds. 1988. Kitaab al-'ayn. 8 vols. Beirut.

Al-Mozainy, Hamza. 1981. Vowel alternations in a Bedouin Hijazi Arabic dialect: Abstractness and stress. Doctoral dissertation, University of Texas at Austin.

Aronoff, Mark. 1994. Morphology by itself: Stems and inflectional classes. Cambridge, Mass.: MIT Press.

Bagemihl, Bruce. 1988. Alternate phonologies and morphologies. Doctoral dissertation, University of British Columbia, Vancouver.

Bagemihl, Bruce. 1989. The crossing constraint and "backwards" languages. Natural Language \& Linguistic Theory 7:481-549.

Banksira, Degif Petros. 2000. Sound mutations: The morphophonology of Chaha. Amsterdam: John Benjamins.

Banksira, Degif Petros. To appear. Words without a lexical category. Lingua Posnaniensis.

Barkai, Malachi. 1980. Aphasic evidence for lexical and phonological representations. Afroasiatic Linguistics 7/6:163-187.

Bat-El, Outi. 1994. Stem modification and cluster transfer in Modern Hebrew. Natural Language \& Linguistic Theory 12:571-596.

Béland, Renée. 1998. Feature geometry and phonemic paraphasias. In The linguistic brain, ed. Parth Bhatt and Ronald Davis, 127-142. Toronto: Canadian Scholars' Press.

Béland, Renée, Monique Bois, Xavier Seron, and Brigitte Damien. 1999. Phonological spelling in a DAT patient: The role of the segmentation subsystem in the phoneme-to-grapheme conversion. Cognitive Neuropsychology 16:115-155.

Béland, Renée, Zohra Mimouni, Ali Idrissi, and Geneviève Duchesne. 2000. Deep dyslexia in two languages of an Arabic-French bilingual patient. Ms., Université de Montréal and Université du Québec à Montréal.

Béland, Renée, and Carole Paradis. 1997. Principled syllabic dissolution in a primary progressive aphasia case. Aphasiology 11:1171-1196.

Berg, Thomas, and Hassan Abd-El-Jawad. 1996. The unfolding of suprasegmental representations: A crosslinguistic perspective. Journal of Linguistics 32:291-324.

Berman, Ruth A. 1981. Language development and language knowledge: Evidence from the acquisition of Hebrew morphophonology. Journal of Child Language 8:609-626.

Blevins, Juliette, and Andrew Garrett. 1998. The origin of consonant-vowel metathesis. Language 74: 508-556.

Blumstein, Sheila. 1973. A phonological investigation of aphasic speech. The Hague: Mouton.

Bohas, Georges. 1997. Matrices, étymons, racines. Leuven: Peeters.

Bohas, Georges, and Jean-Patrick Guillaume. 1984. Étude des théories des grammairiens arabes: Morphologie et phonologie. Damascus: Institut français de Damas.

Borer, Hagit. 1991. The causative-inchoative alternation: A case study in parallel morphology. The Linguistic Review 8:119-158.

Cantineau, Jean. 1950. La notion de "schème", et son altération dans diverses langues sémitiques. Semitica 3:73-83.

Chamora, Berhanu. 1996. Consonant distribution in Inor. In Essays on Gurage language and culture, ed. Grover Hudson, 53-67. Wiesbaden: Otto Harrassowitz.

Cohen, Marcel. 1955. Cinquante années de recherches linguistiques, ethnographiques, sociologiques, critiques et pédagogiques, bibliographie complète. Paris: Imprimerie Nationale-Klincksieck.

Cohen, Marcel. 1970. Traité de langue amharique (Abyssinie). 2nd ed. Paris: Institut d'ethnologie. 
Czaykowska-Higgins, Ewa, and M. Dale Kinkade. 1998. Salish languages and linguistics. In Salish languages and linguistics: Theoretical and descriptive perspectives, ed. Ewa Czaykowska-Higgins and M. Dale Kinkade, 1-68. Berlin: Mouton de Gruyter.

Davis, Stuart, and Bushra Zawaydeh. 1999. A descriptive analysis of hypocoristics in Colloquial Arabic. Language and Linguistics 3:83-98.

Dell, François. 1995. Consonant clusters and phonological syllables in French. Lingua 95:5-26. [Special issue: French phonology: Morae, syllables and the word, ed. Jacques Durand and Marie-Anne Hintze.]

Demisse, Teshome, and M. Lionel Bender. 1983. An argot of Addis Ababa unattached girls. Language in Society 12:339-347.

Diakonoff, I. M. 1988. Afrasian languages. Moscow: Nauka. [Revised edition of 1965 Semito-Hamitic languages: An essay in classification]

Dillmann, August. 1907. Ethiopic grammar. 2nd ed., translated by J. A. Crichton. Amsterdam: Philo Press. Dimmendaal, Gerrit Jan. 1983. The Turkana language. Dordrecht: Foris.

Dressler, Wolfgang. 1990. Phonological paraphasias versus slips of the tongue in German and Italian. In Morphology, phonology, and aphasia, ed. Jean-Luc Nespoulous and Pierre Villiard, 206-212. New York: Springer-Verlag.

Elmedlaoui, Mohamed. 1995. Géométrie des restrictions de coocurrence de traits en sémitique et en berbère: Synchronie et diachronie. Canadian Journal of Linguistics 40:39-76.

Feldman, Laurie Beth, Ram Frost, and Tamar Pnini. 1995. Decomposing words into their constituent morphemes: Evidence from English and Hebrew. Journal of Experimental Psychology 21:947-960.

Frost, Ram, Avital Deutsch, and Kenneth I. Forster. 1997. What can we learn from the morphology of Hebrew? A masked-priming investigation of morphological representation. Journal of Experimental Psychology 23:829-856.

Goldenberg, Gideon. 1994. Principles of Semitic word-structure. In Semitic and Cushitic studies, ed. Gideon Goldenberg and Shlomo Raz, 29-64. Wiesbaden: Otto Harrassowitz.

Guerssel, Mohamed, and Jean Lowenstamm. 1996. Ablaut in Classical Arabic measure I active verbal forms. In Studies in Afroasiatic grammar, ed. Jacqueline Lecarme, Jean Lowenstamm, and Ur Shlonsky, 123-134. The Hague: Holland Academic Graphics.

Harris, Zellig S. 1951. Structural linguistics. Chicago: University of Chicago Press.

Heath, Jeffrey. 1987. Ablaut and ambiguity: Phonology of a Moroccan Arabic dialect. Albany: State University of New York Press.

Hoberman, Robert D. 1988. Local and long-distance spreading in Semitic morphology. Natural Language \& Linguistic Theory 6:544-549.

Hume, Elizabeth. 1998a. Metathesis in phonological theory: The case of Leti. Lingua 104:147-186.

Hume, Elizabeth. 1998b. The role of perceptibility in consonant/consonant metathesis. In Proceedings of the 27th West Coast Conference on Formal Linguistics, 293-307. Stanford, Calif.: CSLI Publications. [Distributed by Cambridge University Press.]

Idrissi, Ali. 1997. Plural formation in Arabic. In Perspectives on Arabic linguistics X, ed. Mushira Eid and Robert R. Ratcliffe, 123-145. Amsterdam: John Benjamins.

Idrissi, Ali. 2000. On Berber plurals. In Research in Afroasiatic grammar, ed. Jacqueline Lecarme, Jean Lowenstamm, and Ur Shlonsky, 101-124. Amsterdam: John Benjamins.

Kazimirski, A. de Biberstein. 1860. Dictionnaire arabe-français. 2 vols. Beirut: Librairie du Liban.

Lecours, André-Roch, and François Lhermitte. 1969. Phonemic paraphasias: Linguistic structures and tentative hypotheses. Cortex 5:193-228.

Leslau, Wolf. 1979. Etymological dictionary of Gurage (Ethiopic), vol. 3. Wiesbaden: Otto Harrassowitz. Leslau, Wolf. 1992. Gurage studies: Collected articles. Wiesbaden: Otto Harrassowitz. 
Lowenstamm, Jean. 1996. CV. In Current trends in phonology, vol. 2, ed. Jacques Durand and Bernard Laks, 419-441. Salford: University of Salford Publications.

Mahadin, Radwan Salim. 1982. The morphophonemics of the Standard Arabic triconsonantal verbs. Doctoral dissertation, University of Pennsylvania, Philadelphia.

McCarthy, John J. 1981. A prosodic theory of nonconcatenative morphology. Linguistic Inquiry 12:373-418.

McCarthy, John J. 1982. Prosodic templates, morphemic templates, and morphemic tiers. In The structure of phonological representations, vol. 2, ed. Harry van der Hulst and Norval Smith, 191-223. Foris: Dordrecht.

McCarthy, John J. 1984. Speech disguise and phonological representation in Amharic. In Advances in nonlinear phonology, ed. Harry van der Hulst and Norval Smith, 305-312. Foris: Dordrecht.

McCarthy, John J. 1989. Linear order in phonological representation. Linguistic Inquiry 20:71-99.

Mimouni, Zohra, Renée Béland, Suzanne Danault, and Ali Idrissi. 1995. Similar language disorders in Arabic and French in an early bilingual aphasic patient. Brain and Language 51:132-134.

Noonan, Michael. 1997. Inverted roots in Salish. International Journal of American Linguistics 63:475-515.

Paradis, Carole, and Fatimzohra El Fenne. 1995. French verbal inflection revisited: Constraints, repairs and floating consonants. Lingua 95:169-204. [Special issue: French phonology: Morae, syllables and the word, ed. Jacques Durand and Marie-Anne Hintze.]

Paradis, Carole, and Jean-François Prunet. 2000. Nasal vowels as two segments: Evidence from borrowings. Language 76:324-357.

Plaut, David C., and Tim Shallice. 1993. Deep dyslexia: A case study of connectionist neuropsychology. Cognitive Neuropsychology 10:377-500.

Prunet, Jean-François. 1996. Guttural vowels. In Essays on Gurage language and culture, ed. Grover Hudson, 175-203. Wiesbaden: Otto Harrassowitz.

Prunet, Jean-François. 1998. When vowels function like consonants. In Phonological studies I, ed. The Phonological Society of Japan, 219-226. Tokyo: Kaitakusha.

Prunet, Jean-François, and Berhanu Chamora. To appear. The canonical shapes of Gurage verbs. In New data and new methods in Afroasiatic linguistics: Dedicated to the memory of Robert Hetzron, ed. Andrzej Zaborski. Wiesbaden: Otto Harrassowitz.

Ratcliffe, Robert R. 1997. Prosodic templates in a word-based morphological analysis of Arabic. In Perspectives on Arabic linguistics X, ed. Mushira Eid and Robert R. Ratcliffe, 147-171. Amsterdam: John Benjamins.

Rose, Sharon. 1997. Theoretical issues in comparative Ethio-Semitic phonology and morphology. Doctoral dissertation, McGill University, Montréal.

Safi-Stagni, Sabah. 1991. Agrammatism in Arabic. In Perspectives on Arabic linguistics III, ed. Bernard Comrie and Mushira Eid, 251-270. Amsterdam: John Benjamins.

Safi-Stagni, Sabah. 1995. Morphological structure and lexical processing: Evidence from Arabic. In Perspectives on Arabic linguistics VII, ed. Mushira Eid, 93-106. Amsterdam: John Benjamins.

Saussure, Ferdinand de. 1978. Cours de linguistique générale. Paris: Payot.

Schmidt, Deborah. 1994. Phantom consonants in Basaa. Phonology 11:149-178.

Stemberger, Joseph P. 1983. Speech errors and theoretical phonology: A review. Indiana University Linguistics Club, Bloomington.

Tranel, Bernard. 1995. Current issues in French phonology: Liaison and position theories. In The handbook of phonological theory, ed. John A. Goldsmith, 798-816. Cambridge, Mass.: Blackwell.

Ussishkin, Adam Panter. 1999. The inadequacy of the consonantal root: Modern Hebrew denominal verbs and output-output correspondence. Phonology 16:401-442.

Valdois, Sylviane, and Jean-Luc Nespoulous. 1994. Perturbations du traitement phonétique et phonologique du langage. In Neuropsychologie humaine, ed. Xavier Seron and Marc Jeannerod, 360-374. Liège: Mardaga. 
Versteegh, Kees. 1997. Landmarks in linguistic thought III: The Arabic linguistic tradition. London: Routledge.

Zaborski, Andrzej. 1991. Biconsonantal roots and triconsonantal root variation in Semitic: Solutions and prospects. In Semitic studies in honor of Wolf Leslau on the occasion of his 85th birthday, vol. 2, ed. Alan S. Kaye, 1675-1703. Wiesbaden: Otto Harrassowitz.

Zawaydeh, Bushra, and Stuart Davis. 1999. Hypocoristic formation in Ammani-Jordanian Arabic. In Perspectives on Arabic linguistics XII, ed. Elabbas Benmamoun, 113-139. Amsterdam: John Benjamins.

(Prunet)

Université du Québec à Montréal

Department of Linguistics

P.O. Box 8888, Station Central

Montréal, Québec

Canada H3C $3 P 8$

prunet.jean-francois@uqam.ca

(Béland)

Centre de Recherche

Institut Universitaire de Gériatrie de Montréal

4565 Queen Mary Road

Montréal, Québec

Canada H3W 1 W5

renee.beland@umontreal.ca

(Idrissi)

Université du Québec à Montréal

Department of Linguistics

P.O. Box 8888, Station Central

Montréal, Québec

Canada H3C $3 P 8$

ali.idrissi@eudoramail.com 